\title{
Reciprocal constructions in Homeric Greek: a typological and corpus-based approach
}

\author{
Guglielmo Inglese (KU Leuven) \& Chiara Zanchi (Università degli Studi di Pavia)
}

\begin{abstract}
Ancient Greek features a wide array of means to encode reciprocity. Even though reference grammars do mention most of these strategies, they have not been brought together and compared in a systematic way so far. In this paper, we provide a thorough corpus-based description of the three most widespread reciprocal markers in Homeric Greek: the pronoun allélōn, the middle voice, and the use of preverbs. Our analysis is couched within current descriptive models of reciprocal constructions developed in linguistic typology. As we argue, Homeric Greeks offers a remarkably complex picture, whereby these strategies synchronically cover different semantic and syntactic sub-domains of reciprocity, and thus partly stand in complementary distribution. Already in Homer, the pronoun allélōn is the most productive marker of reciprocal situations, with the middle voice and preverbs playing a more limited role. By adopting a diachronic perspective, we also show that this distribution can partly be explained as the result of the different historical sources of each construction. Moreover, once properly scrutinized, the facts of Homeric Greek provide interesting cues as to the developments of reciprocal constructions in later stages of Greek.
\end{abstract}

Keywords: reciprocal constructions, reciprocal pronoun, middle voice, preverbs, Homeric Greek

\section{Introduction}

In this paper, we provide a description of the main reciprocal constructions (henceforth $\mathrm{RCs}$ ) in Homeric Greek (henceforth HG). The last decades have witnessed an increased interest in RCs of ancient Indo-European (henceforth IE) languages (Krisch 1999 for an overview). Detailed descriptions of RCs in individual languages include Latin (Fanelli 2009; Cuzzolin 2015), Vedic (Kulikov 2007, 2014a), and Hittite (Inglese 2017). However, up to now, a comprehensive account of Ancient Greek (henceforth AG) is still lacking and remains a desideratum. Indeed, early and recent 
grammars of AG (e.g. Schwyzer \& Debrunner 1950; Chantraine 1953; Crespo, Conti \& Maquiera 2003) do not include a section that discusses RCs altogether. In these grammars, only reciprocal pronouns are normally reserved dedicated sections, while other strategies (on which, cf. Section 3 below) are only cursorily mentioned at best. More recent studies devoted to individual RCs at different stages of AG have also appeared (e.g. Conti 2006; Revuelta 2007, 2010), but these lack a more general perspective on how the various strategies relate to one another.

This paper aims to partly fill this gap and offers a systematic description of the main RCs in HG. As compared to the existing accounts of AG RCs in grammars and previous studies, this work innovates in two main respects. The former concerns our theoretical background: in order to provide a sound description of RCs, we frame our analysis within the up-to-date typology of RCs. The latter is methodological: in this paper, we adopt a corpus-illustrated approach, and describe RCs based on the thorough analysis of all their occurrences in the Homeric corpus.

Overall, the paper has a threefold aim. In the first place, we aim to provide a systematic and synchronic description of the three main RCs in Homer: the reciprocal pronoun allélōn, the middle voice, and preverbs. The second aim is to explore the distribution of these strategies in relation to one another, in order to understand how they carve up the reciprocal domain and whether they display a preference for specific semantic or morphosyntactic sub-domains (on which, cf. Section 2). In the third place, we touch upon the diachrony of these RCs. On the one hand, we put forward hypotheses about their possible origin. On the other hand, based on the Homeric data, we briefly sketch trends in the development of RCs that can be observed in the later history of Greek.

The paper is structured as follows. In Section 2, we lay out the theoretical background of our analysis and discuss possible parameters of classification of RCs, as elaborated in linguistic typology. After a methodological note (Section 3.1), Section 3 features a thorough description of three RCs in HG: the reciprocal pronoun allêlōn (Section 3.1), the middle voice (Section 3.3), and preverbs (Section 3.4). Building upon the findings of Section 3, in Section 4, we proceed to a systematic comparison among the three RCs and outline a more general description of how reciprocity is encoded 
in HG. Finally, we discuss a number of diachronic aspects concerning the RCs under investigation in Section 5. Section 6 summarizes the results of the paper.

\section{Reciprocal constructions in linguistic typology: parameters of classification}

Over the past decades, RCs have been a major topic in linguistic typology, so that we now know a great deal about how reciprocity is encoded in the languages of the world and how RCs vary across languages. Typological studies have progressively brought to light the complexity of the reciprocal domain and have shown that languages resort to a wide array of morphosyntactic strategies to encode reciprocal situations (see e.g. Frajzyngier \& Curl 2000; König \& Kokutani 2006; Nedjalkov et al. 2007; König \& Gast 2008; Evans et al. 2011). A detailed discussion of typological approaches to reciprocity goes beyond the scope of this paper. However, since in what follows we ground our analysis of AG RCs on typological parameters, we find it useful here to briefly describe some of these theoretical notions in more detail.

From a functional perspective, we define a canonical reciprocal situation as one featuring at least two participants, termed reciprocants, that (a) are in the identical reverse relation to each other and (b) perform two identical semantic roles each (Kemmer 1993: 95-127; Nedjalkov 2007a: 6-7). In other words, the relationship that RCs establish is typically simultaneous, inverse, and symmetric (cf. Cuzzolin 2015). However, this is not exhaustive of the possible reciprocal situation types: less canonical reciprocal configurations do exist, including asymmetric and sequential (i.e. nonsimultaneous) ones and those involving more than two participants (cf. Nedjalkov 2007a: 26; BarAsher Siegal 2014: 338-342; see Darlymple et al. 1998; Maslova 2008: Evans et al. 2011 i.a. for the full inventory of possible reciprocal configurations and their relevance for linguistic encoding). For the purpose of our study, it is also important to implement another semantic distinction, i.e. that between spatial (e.g. mix, be close) and non-spatial or proper reciprocals (e.g. fight, be similar; cf. Nedjalkov 2007a: 13), since, as we discuss, the distribution of the various RCs is sensitive to the (non-)spatial semantics of the reciprocal situation. 
RCs can be classified according to different structural and morphosyntactic parameters (see e.g. Haspelmath 2007; König \& Gast 2008). For the goals of this paper, one distinction worth mentioning is the one between grammatical and lexical reciprocal classes (Nedjalkov 2007a: 10-14). Grammatical reciprocals are derived through the operation of reciprocalization from two-place nonreciprocal verb bases, as in e.g. $A$ hits $B>A$ and $B$ hit each other. The class of lexical reciprocals is more heterogeneous than the grammatical one, as has already been observed for AG by Conti (2006: 172). The class of lexical reciprocals includes (i) reciproca tantum, i.e. verbs that are morphologically marked as reciprocals and lack a non-reciprocal counterpart, e.g. AG mákhomai:MID 'fight'; (ii) lexicalized reciprocals, i.e. verbs that have a non-reciprocal counterpart but "whose meaning is not a mere sum of the meaning of the base and the meaning 'each other'” (Nedjalkov 2007a: 14), e.g. amphiépomai 'crowd about' vs. hépomai 'follow'; (iii) verbs that inherently express reciprocal situations without reciprocal marking, e.g. polemízō:ACT 'fight'. More generally, lexical reciprocals tend to lexicalize situations that have a strong association with the semantic component of symmetry (Kemmer 1993: 100-108; Knjazev 2007; Dimitriadis 2008).

Such a distinction between lexical and grammatical reciprocals is not entirely new to AG linguistics. Already Conti (2006) suggested treating verbs that are inherently reciprocals differently from verbs that may have a reciprocal interpretation only when they receive special marking, be it either through the reciprocal pronoun or through the middle voice (in her discussion, preverbs are not explicitly accounted for).

\section{The encoding of reciprocity in Homeric Greek}

As common to many languages of the world, AG features several means to encode reciprocity. Most of them are mentioned but not thoroughly dealt with in reference grammars (e.g. Schwyzer \& Debrunner 1950; Chantraine 1953; Crespo, Conti \& Maquiera 2003), and there exist studies dedicated, in whole or in part, to individual reciprocal situations or encoding strategies (e.g. Conti 2006 on lexical reciprocals; Revuelta 2007 on reciprocal preverbs, Revuelta 2010 on the reciprocal 
pronoun allélōn). However, as already remarked by Conti (2006: 169), a unified account of how these strategies relate to one another and build up a complex system to encode reciprocity is still lacking.

In the following sections, we concentrate on three main RCs in $\mathrm{HG}$, viz. the reciprocal pronoun allélōn, verbal voice, and preverbs. These do not represent the exhaustive inventory of all Homeric means to encode reciprocal situations. More marginal strategies are also attested (cf. Schwyzer \& Debrunner 1950: 198-199, 233, 665), but for reasons of space, we leave them for future study and only succinctly present them in what follows. These strategies are marginal not only on account of their low frequency, but also in that they cannot be said to constitute conventionalized means of encoding reciprocity, as their reciprocal interpretation is often strongly context-dependent in HG and remains such in the later language as well. ${ }^{1}$

To begin with, reciprocal situations can be expressed by bi-clausal constructions, as in (1), where the couple of personal pronouns soì mèn egố, sù d' emoí 'I to you and you to me' is used to underscore the reciprocal interpretation of the verb hupoeixomen 'give way', which is also explicitly expressed by allêloisi 'one to the other'. Bi-clausal constructions such as that in (1) represent the maximally iconic strategy that is available for encoding reciprocity to the languages of the world (Maslova \& Nedjalkov 2005), so its occurrence in HG is by no means surprising.

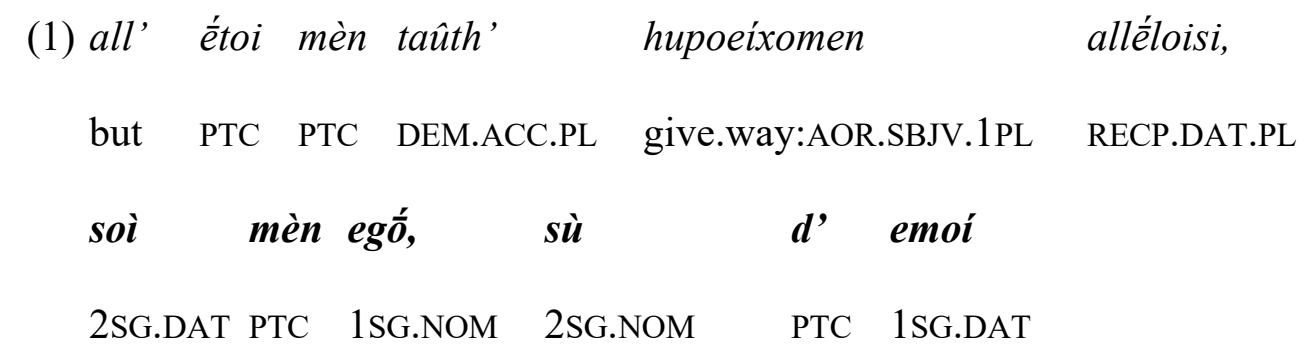

'Come then, in this thing let us both give way to each other, I to you, you to me.' $(I l .4 .63)^{2}$

\footnotetext{
${ }^{1}$ As an anonymous reviewer pointed out, preverbs are also non-conventionalized as reciprocal markers in Homer. Hwever, they later on grammaticalize and enjoy a much wider distribution (cf. especially Sections 3.4 and 5). This development is not shared by other marginal strategies, which remain such throughout the history of Greek.

${ }^{2}$ In glosses, we only include number if not singular (singular number is consistently glossed in personal pronouns and verbs only), gender if relevant to understand agreement patterns with nominal modifiers, mood if not indicative, and voice
} 
Demonstrative pronouns can also receive reciprocal interpretation in specific contexts: consider example (2), in which the demonstrative pronoun autô̂s literally '(in) these' is to be interpreted as 'among themselves'. Notably, this interpretation is likely triggered by the occurrence of the inherently reciprocal noun éris 'quarrel' (here in the accusative case).

(2) en d' autô̂s rérida bareñanto

in PTC DEM.DAT.PL quarrel(F):ACC break:IMPF.3PL.M/P heavy:ACC.F

'And (the gods) broke out among themselves the weight of their quarrel.' (Il. 20.55)

In addition, reciprocity can be occasionally encoded by polyptotic constructions, i.e. constructions featuring the repetition of the same NP in two different syntactic positions, as in (3).

(3) hoì dè lúkoi hò̀s allếlois epórousan, anè̀r d' REL.NOM.PL PTC wolf:NOM.PL like RECP.DAT.PL spring:AOR.3PL man:NOM PTC ándr’ ednopálizen

man:ACC fling.down:IMPF.3SG

'Who like wolves sprang upon one another, man was overthrowing man.' (Il. 4.472)

In example (3), the repetition of the generic noun anè̀r 'man' in both subject and object positions triggers a reciprocal interpretation of the situation, so that the sentence could also be translated as 'the men overthrew one another'. Note further that, similarly to what we observe in (1), the reciprocal interpretation of the polyptoton anèr...ándra is reinforced by the occurrence of the pronoun allếlois

if not active. Glosses generally follow the Leipzig Glossing Rules (https://www.eva.mpg.de/lingua/pdf/GlossingRules.pdf). To the latter we added a number of language-specific labels: $\mathrm{AOR}=$ aorist, $\mathrm{M} / \mathrm{P}=$ medio-passive, $\mathrm{PTC}=$ particle. Authors' and texts' abbreviations follow: Hdt. = Herodotus, Hist. $=$ Histories, Il. =Iliad, Od. $=$ Odyssey. 
in the preceding context. Polyptotic constructions of this type instantiate the so-called REPETITION schema (Heine \& Miyashita 2008: 182), which is one of the cross-linguistically most common strategies to encode reciprocity (Nedjalkov 2007b: 154). This strategy is attested e.g. in Semitic (BarAsher Siegal 2014: 345) and other ancient IE languages, e.g. Latin vir virum, homo homini, and Sanskrit śúras śúram (cf. Krisch 1999). ${ }^{3}$

Adjectives and adverbs constitute another marginal source of reciprocal constructions. Certain adjectives indicate reciprocal properties by virtue of their inherent lexical meaning. A case in point is ísos 'equal' (often construed with a second participant in the dative case) as in (4):

$\begin{array}{rrllll}\text { (4) ou mèn soí } & \text { pote îson } & \text { ékhō } & \text { géras } \\ \text { NEG } & \text { PTC } & \text { 2SG.DAT } & \text { PTC } & \text { equal:ACC.N } & \text { have:PRS.1SG prize(N):ACC }\end{array}$

'Do I have a prize that is equal to you (i.e. to your prize).' (Il. 1.163)

Finally, HG features a number of adverbs that can be added to verbs encoding reciprocal situations but that cannot encode reciprocity by themselves. For example, the adverbs antía, antíbion, enantibion, enantion, antikrú 'in front of' are all attested in Homer with the reciprocal verb mákhomai 'fight'. These adverbs can be thus more specifically classified as reciprocal specifiers, as in the case of e.g. German gegenseitig (Nedjalkov 2007b: 164).

\subsection{Methodology}

In this section, we briefly outline the methodological premises on which the paper rests, concerning both the data selection and the criteria behind the data analysis.

\footnotetext{
${ }^{3}$ Notably, in most IE languages the use of such constructions remains sporadic, as it is in Homeric Greek, but in some languages polyptotic constructions enjoyed a remarkable productivity and became a standard means to encode reciprocity. A case in point is Hittite, where the polyptotic construction based on the noun ara- 'fellow' evolved into a full-fledged reciprocal marker (cf. Inglese 2017; see further Kulikov 2014 for Germanic and Slavic comparanda).
} 
For the purpose of this paper, we focus our attention on HG. We are well aware that working with the Homeric poems as a source of linguistic evidence poses several challenges, and that HG cannot simply be taken as a monolithic language variety. As is well-known, the linguistic variety attested by the Iliad and the Odyssey is an archaic eastern Ionic, enriched by some Mycenean and Aeolic traits, as well as by a number of other features that are difficult to ascribe to any particular dialectal variety (Horrocks 2010: 44). This admixture can be explained by taking into consideration that the Iliad and the Odyssey are examples of oral poetic diction (Lord 1960; Parry 1971). Though these poems were probably recorded in writing during the $8^{\text {th }}$ century $\mathrm{BC}$, they preserve more ancient layers of the Greek language, from at least two centuries earlier, especially within fixed formulas (i.e. recurring conventionalized locutions to express certain concepts). Precisely because of their formulaic language, the Iliad and the Odyssey are of inestimable value for linguistic reconstruction, as they often preserve traces of rather old linguistic material (cf. e.g. Watkins 1976).

In fact, the Homeric language is extremely interesting in several respects. To begin with, HG constitutes the oldest documented (literary) variety of AG. As such, not only is it of primary importance for historical comparative research, as we mentioned above, but it also provides an invaluable baseline to fully appreciate the perspective diachrony of later Greek. Moreover, the Homeric poems can be with due care analyzed from a synchronic perspective, as shown by the several studies that have successfully described individual linguistic traits of Homeric Greek from a synchronic perspective (Horrocks 1981; various studies included in Logozzo \& Poccetti 2017).

The reason to work on Homer is also of practical nature. Homeric Greek can easily be studied with the methods of corpus linguistics thanks to several available digital resources, including AGLDT 2.0, HoDeL 2.0, and The Chicago Homer. AGLDT 2.0 is a dependency (i.e. verb-centered) treebank of AG and Latin, currently under development and maintenance at University of Leipzig and Tufts University. ${ }^{4}$ It contains various AG and Latin texts, including the Homeric poems, fully and manually

\footnotetext{
4 AGLDT 2.0 data and documentation can be freely consulted and downloaded from Github (https://perseusdl.github.io/treebank_data/).
} 
annotated at a morphosyntactic layer. Out of $A G L D T 2.0, H o D e L$ 2.0. was automatically induced by extracting all Homeric verbal forms together with their supposedly argumental dependents and metadata associated with them (on the structure of HoDeL 2.0 and the issues faced during its construction, cf. Zanchi et al. 2018). Thus, HoDeL 2.0 constitutes a dependency lexicon for Homeric Greek, from which Homeric verbal forms and argument structure constructions can be easily queried through a user-friendly interface..$^{5}$ The Chicago Homer contains the Early Greek epic texts together with their aligned translation and annotation. In particular, metadata at The Chicago Homer comprises morphological, narratological, and stylistic information. In this respect, The Chicago Homer offers a complementary point of view on the Homeric poems with respect to AGLDT 2.0 and HoDeL 2.0, which are more focused on the morphosyntactic layer. ${ }^{6}$

All our Homeric data has been extracted from the above-mentioned linguistic resources. Thus, our investigation can be regarded as corpus-illustrated (on the difference between corpus-driven and corpus-illustrated studies, cf. e.g. Tummers, Heylen \& Geeraerts 2005). In order to retrieve all the relevant data for each construction under analysis, we had to rely on a semi-automatic extraction procedure. Data on the reciprocal pronoun was easily retrievable, since we simply queried the $A G L D T$ 2.0 for the lemma allélōn and automatically extracted all of its tokens. Data on the middle voice and on preverbs was more difficult to extract. Concerning the middle voice, we automatically extracted from HoDeL 2.0 a full list of middle verbs and their occurrences. Among these, also based on crosschecking with the $L S J$, we only selected verbs that potentially had a reciprocal meaning, and for these we manually checked all occurrences to verify that the verbs actually occurred in contexts in which they expressed reciprocity. Similarly, for preverbs data extraction has been two-fold. The first stage consisted of a manual lookup in the $L S J$; secondly, we automatically extracted the relevant passages

\footnotetext{
${ }^{5}$ HoDeL 2.0 is still being developed at University of Pavia. It can be currently consulted at the following link (https://alessiopalmero.unipv.it/hodel/).

6 In this paper, the Homeric texts and their translation are taken/adapted from The Chicago Homer (http://homer.library.northwestern.edu).
} 
from HoDeL 2.0, and selected only those in which a reciprocal meaning was clearly discernible. As for the diachrony of Greek RCs, which is preliminary touched upon in Section 5 and whose thorough discussion far exceeds the scope of this paper, our data mainly relies on secondary materials, taken from a number of lexicographic and grammatical resources $\left(D E L G ; L I P P ; L I V^{2} ; L S J\right.$; Schwyzer \& Debrunner 1950; Chantraine 1953; Beekes 2010; Crespo, Conti \& Maquiera 2003) as well as specific studies dedicated to one or more RCs in the history of Greek and other IE languages (e.g. Mackridge 1985; Krisch 1999; Allan 2003; Asproudi 2005; Kulikov 2007; Fanelli 2009; Inglese 2017).

Table 1 displays a raw quantitative overview of the material resulting from the data extraction. In Table 1, "type" refers to the number of different lemmas with which each strategy is attested, whereas the token frequency refers to the total amount of occurrences taken into consideration. A more finegrained quantitative description of distribution of each strategy will be given in Sections 3.2-3.4.

Table 1: Quantitative overview of the material

\begin{tabular}{|l|l|l|}
\hline & Types & Tokens \\
\hline allélōn & 98 & 176 \\
\hline Middle voice & 80 & 672 \\
\hline Preverbs & 33 & 103 \\
\hline
\end{tabular}

In analyzing the data from the corpus, we combine a number of different morphosyntactic as well as semantic parameters. Whereas some of these parameters are relevant for only one of the constructions under analysis, others pertain to all of them. For the sake of clarity, we briefly introduce them here.

The first parameter concerns the type of predicate that the $\mathrm{RC}$ occurs with, with a distinction between lexical and grammatical reciprocals on the one hand and spatial and proper reciprocals on the other hand, as discussed in Section 2. For preverbs, we also took into account the semantics of 
the simplex verbs onto which preverbs attach. Two further semantic parameters relate to the type of reciprocal situation encoded and to the temporal unfolding of the event. Concerning the situation types, elaborating upon previous insights from Kemmer (1993: 96-127), Maslova (2008: 228-248), and Evans (et al. 2011: 8-12 and passim) among others, we came to identify five different types: (i) binary, in which the two reciprocants are fully distinguishable and the reciprocal event can be decomposed in two symmetrical and distinct sub-events (e.g. they hit one another); (ii) unary, in which the event can be conceptualized as an indivisible whole, and it is not easy to detect the contribution of the individual participants and to decompose the event in two more basic sub-events (e.g. they met); (iii) strong reciprocals, in which reciprocity is established among all entities in a set (e.g. they all know each other well); (iv) weak reciprocity, in which reciprocity does not hold for every member of the set with respect to all others, but only between individual pairs (e.g. the soldiers killed one another); (v) chaining, in which reciprocity is established in a chain-like fashion between at least three entities (e.g. the boys followed one another). The third parameter, i.e. temporality, refers to whether the two sub-events that make up the reciprocal event occur simultaneously (e.g. they hug each other) or take place in a sequence (e.g. over the years, they wrote letters to one another). In order to classify the RCs of Homeric Greek according to these situation types, we resorted to a careful evaluation of the wider contexts in which they occurred.

Two additional parameters are morphosyntactic in nature. First, we consider the diathesis of the RC. We follow Nedjalkov (2007a: 54-69) and use the term diathesis in a narrow sense to refer to the syntactic role of the two reciprocants of a RC (the term should be thus kept distinct from verbal voice, see Section 3.2; on the terminological distinction between voice and diathesis, see e.g. Kulikov 2013). The major distinction consists in whether the second participant is an argument of the verb or not (we return below on the criteria for assessing argumenthood in Homeric Greek, cf. fn. 7 and 10). In this sense, we distinguish subject- and object-oriented reciprocals, from adverbials and possessive ones.

The last parameter is the syntactic construction in which RCs occur in. Following Nedjalkov (2007a: 27), we operate a threefold distinction between simple, discontinuous and absolute 
constructions. In simple constructions both reciprocants are encoded as having the same syntactic role (e.g. Peter and Mary fought); in discontinuous constructions, one of the two reciprocant receives a different encoding, often as an oblique (e.g. Peter fought against Mary). Finally, we take absolute constructions as those in which only one reciprocant is overtly expressed, whereas the second one is left implicit altogether (e.g. Peter fought in WWII).

When analyzing our corpus data, all of the aforementioned parameters have been taken into account one at a time. However, we are well aware that some of these features may cluster together, as certain reciprocal situations are characterized by certain stable co-occurring features. For example, unary situations types also tend to be simultaneous, as they comprise a single event. In Sections 3.2 to 3.4 we discuss the introduced parameters, limiting ourselves to those that are relevant for each RC.

\subsection{The reciprocal pronoun allélōn 'each other'}

As is well-known, AG features a dedicated reciprocal pronoun allélōn 'each other' (Schwyzer \& Debrunner 1950: 198-199; Crespo, Conti \& Maquiera 2003: 47-48; Revuelta 2010). This pronoun is already frequent in the Homeric poems, for a total frequency of 176 tokens (data from AGLDT 2.0). In Sections 3.2.1-3.2.5, we discuss several relevant aspects concerning its distribution.

\subsubsection{Head type}

The first aspect concerns the type of head upon which the pronoun can depend. As shown in Table 2, the reciprocal pronoun depends on a variety of head types, with a strong preference for verbal heads, i.e. it most frequently occurs as a verbal argument. ${ }^{7}$ Concerning the frequency of individual heads, it

\footnotetext{
${ }^{7}$ Given the controversial status of preverbs in Homer (see Section 3.4. for details), in several cases it is admittedly difficult to assess whether the pronoun depends on a prepositional head or on a verb with a preverb in tmesis (on tmesis in AG and in other ancient IE languages, cf. among others Watkins 1963, 1964; De Angelis 2004 with references; Hajnal 2004; Romagno 2004; Haug 2011; Bertrand 2014; Zanchi forthc.: Ch. 3.1.2. and 5.1.2.2. with references therein). For example, the pronoun occurs with the verb keîmai 'lie' in a sentence such as keiat' ep' allêloisin 'and lay upon each other' (Od. 22.389). Given that neither keîmai nor the compound verb epi-keimai (cf. epékeinto:IMPF.3PL.M/P in Od. 6.19) take the prepositionless Dative, one can reasonably assume that in keiat' ep' alléloisin it is ep'(i) to function as a prepositional
} 
is noteworthy that, out of the 98 lemmas with which the pronoun combines, $67(68 \%)$ are hapaxes. This means that the pronoun is freely used as a means of deriving RC out of several distinct bases. ${ }^{8}$

Table 2: Frequency of head types

\begin{tabular}{|l|l|l|l|l|l|l|}
\hline Head Type & Verb & PV...Verb & Noun & Adjective & Adverb & Total \\
\hline Type Frequency & 60 & 19 & 10 & 5 & 4 & $\mathbf{9 8}$ \\
\hline Token Frequency & 79 & 68 & 13 & 10 & 6 & $\mathbf{1 7 6}$ \\
\hline
\end{tabular}

\subsubsection{Predicate type}

Zooming in on those cases in which the pronoun depends on a verb, the second parameter under evaluation concerns the type of verbal predicates with which the pronoun occurs. Specifically, we investigated the association of the pronoun with lexical and grammatical reciprocals on the one hand, and with spatial and proper reciprocals on the other hand. The possible combinations are illustrated in examples (5) to (8).

(5) Proper grammaticAL

bállon $\quad d$ allélous khalkéresin egkheiéisin

head of the pronoun. Instead, the case of ep' allêloisin órousan (Il. 14.401) vs. allélois epórousan 'they drove against one another' (Il. 4.472) is more complex: since the dative pronoun alléloisin occurs both with the separated and univerbated preverb and the PP epi +DAT is taken by the verb only in this syntactic configuration (cf. Il. 15.726), it is reasonable to assume that alléloisin depends in both cases on the verbal head, irrespective of the positioning of its preverbal modifier. Similar cases are grouped together in Table 1 under the "PV...Verb" category. The prepositional status of the so-called "preverb" is unambiguous only in one passage: ándres ep' allếlous nēusìn peróōsi thálassan 'they often cross the sea with ships to each other.' (Od. 9.129). In this example, the verb peróosi:Prs.3PL takes its own accusative direct object thálassan 'sea', and the prepositional phrase ep' allêlous 'to each other' clearly behaves as an adjunct.

${ }^{8}$ The number of hapaxes is even higher once the effects of Homeric formulaic language are taken into account (Bozzone 2014, and references therein). When the pronoun occurs more than once with the same verbal head, it is often the case that the entire verse is formulaic. For example, the pronoun often occurs within the formulas hòs hoi mèn toiaûta pròs allếlous agóreuon 'so they said such things to each other' (28 tokens) and hoì d' hóte dè skhedòn ềsan ep' allếloisin ióntes 'now as these in their advance had come close together' (10 tokens) (data from The Chicago Homer). 
throw:IMPF.3PL PTC RECP.ACC.PL bronze:DAT.PL.F spear(F):DAT.PL

'And they were throwing at each other with bronze-headed spears.' (Il. 18.534)

(6) PROPER LEXICAL

hōs d' Eûrós te Nótos t' eridaíneton alléloiïn

as PTC E.:NOM and N.:NOM and fight:PRS.3DU RECP.DAT.DU

'As Euros and Notos the it out with each other.' (Il. 16.765)

(7) SPATIAL GRAMMATICAL

hò̀s Trôes kaì Akhaioì ep' alléloisi thoróntes

so T.:NOM.PL and A.:NOM.PL on RECP.DAT.PL spring: PTCP.AOR.NOM.PL

'So Trojans and Achaians springing against one another...' (Il. 16.770)

(8) Spatial LeXicAL

epeì thamà tô̂on emisgómeth' alléloisi

since often such mix:IMPF.1PL.M/P RECP.DAT.PL

'Since we ever so often got together with each other.' (Od. 1.20)

In examples (5) and (6), the pronoun occurs with predicates that indicate a non-spatial relationship between the reciprocants. ${ }^{9}$ Instead, these two examples vary according to the grammatical vs. lexical parameter. In (5) the pronoun combines with a grammatical reciprocal verb, as the verb bállō 'throw' lexicalizes an asymmetrical situation, which receives a reciprocal interpretation only when combined with the pronoun allêlōn. By contrast, in (6) the pronoun occurs with a reciprocal verb that has an inherently reciprocal semantics, i.e. eridaino 'fight'. Similarly, in both examples (7) and (8), the reciprocal pronoun occurs with verbs that indicate spatial reciprocal situations. However, in (7) the verb is a grammatical reciprocal, as the verb base thoróo 'spring' does not have a reciprocal meaning per se, whereas in (8) a spatial lexical reciprocal verb, mignúmi 'mix, mingle', occurs.

\footnotetext{
${ }^{9}$ Indeed, example (5) does contain a caused motion verb, i.e. bállō 'throw'. However, the reciprocal situation is not of the spatial type, as the reciprocants themselves do not perform any movement.
} 
Examples (5) to (8) suggest that the pronoun occurs with all types of predicates, irrespective of their semantics. Whereas this is descriptively true, a closer look at the corpus data unveils a slightly different picture and suggests that the pronoun is preferably employed with proper reciprocals of the grammatical type (see Section 4).

\subsubsection{Morphological features}

The pronoun allếlōn shows a full inflectional paradigm, and inflects for gender, number, and case (with the exception of the nominative case). In Table 3, we summarize data concerning the pronoun's case and number inflection. Concerning case inflection, the dative case is the most frequent. This is hardly surprising, since, as we discuss in Section 3.2.4, higher frequency of the dative can be easily explained by the fact that the dative is often the case of the second argument of verbs of social interaction, which include many inherently reciprocal situations such as 'fight' and 'meet' (see also Conti 2006: 175-182; Sausa 2015: 150-136). With respect to number inflection, one observes that the pronoun inflects in the dual only in a handful of occurrences (cf. Table 3), which is surprising given that prototypical reciprocal situations involve two participants. However, a closer look at the passages containing allêlōn shows that there is a mismatch between number inflection and the actual number of reciprocants involved. In fact, the pronoun occurs in contexts that involve only two entities in 80 passages (vs. 96 passages with more than two entities involved), but only in 8 out of such 80 occurrences does the pronoun inflect in the dual. This distribution is not entirely surprising, since it is well-known that, already in Homeric Greek, the plural is frequently used instead of the dual in contexts in which only two entities are involved (cf. Viti 2011).

Table 3: Inflectional features of reciprocal pronouns

\begin{tabular}{|l|l|l|}
\hline \multicolumn{2}{|l|}{ Case } \\
\hline ACC. & GEN. & DAT. \\
\hline
\end{tabular}




\begin{tabular}{|l|l|l|}
\hline 60 & 32 & 84 \\
\hline Number & \multicolumn{2}{|l|}{} \\
\hline PLURAL & DUAL \\
\hline 168 & 8 \\
\hline
\end{tabular}

\subsubsection{Diathesis}

As discussed in Section 3.1, diathesis refers to the syntactic configuration of the two reciprocants (Nedjalkov 2007a: 54-69). The major distinction concerns the status of verbal arguments of the reciprocants. ${ }^{10}$ Reciprocalization that does not involve arguments includes the adverbial and the possessive configurations, as exemplified in (9) and (10) respectively.

(9) ADVERBIAL
tà
mèn katéthent'
epì gaièi
plēsíon
allélōn
DEM.NOM.PL.N PTC lie.AOR.3PL.MID on earth.DAT close.to RECP.GEN.PL

'They laid these (i.e. their armors) on the ground, close to one another.' (Il. 3.115)

(10) Possessive
égkhea
d' allélōn
aleốmetha
kaì di’ homílou
spear:ACC.PL PTC RECP.GEN.PL avoid:SBJV.PRS.1PL.M/P also through fight:GEN

\footnotetext{
${ }^{10}$ Assessing the argumenthood of verbal participants in Homeric Greek is a notoriously intricate issue, as discussed at length in Zanchi et al. (2018 with references therein). Among possible diagnostics to distinguish argument participants from adjuncts, in this paper we take into account the following ones: (i) arguments are obligatorily expressed for a certain predicate, with the exception of those constructions in which null referential objects are syntactically conditioned in Homeric Greek, the latter including coordinated clauses, coordinated verbs, and conjunct participles (for a full discussion of referential object omission in AG, cf. Luraghi 2003a; Keydana \& Luraghi 2012; Haug 2012; Sausa \& Zanchi 2015); (ii) arguments are generally required by the verbal semantics (for a frame approach to this point, limited to a number of AG motion verbs, cf. Georgakopoulos 2018); (iii) arguments take a case or/and are introduced by a preposition that is selected by the predicate (the relationship holding between a predicate and an argument is a government relation). Each of the above diagnostics, taken per se, does not constitute a necessary or a sufficient condition for argumenthood: their combination however can help the linguist evaluate the argumental status of verbal dependents.
} 
'Let us avoid each other's spears, even in the close fighting.' (Il. 6.226)

In example (9), a spatial adverbial reciprocal relationship is established between the entities laid on the ground, and is encoded by the adverbial neuter plēsion 'close to (+GEN)'. The function of the phrase plèsion allếlōn is to further specify the spatial relationship among the objects of the verb katéthent', and is therefore adverbial in nature. Similarly, in (10) the second participant is a possessive modifier of the NP égkhea 'spears', and the pronoun accordingly inflects in the genitive case.

More commonly, reciprocalization involves participants that syntactically behave as verbal arguments. Based on the syntactic role of the first reciprocant, one can distinguish between subjectand object-oriented reciprocals. With subject-oriented reciprocals, one reciprocant stands in subject position and the second one can either be syntactically an object (direct) or a third argument of trivalent verbs (indirect). Object-oriented reciprocals are characterized as those in which reciprocalization is established between the direct object and another non-subject participant of the clause. Examples of subject-oriented indirect and object-oriented reciprocals are given in (11) and (12) respectively.

(11) SUBJECT-ORIENTED INDIRECT

dôra d' ág' allếloisi periklutà dồmen ámphō gift(N):ACC.PL PTC PTC RECP.DAT.PL glorious:ACC.PL.N give:SBJV.AOR.1PL both 'Come then, let us give each other glorious presents.' (Il. 7.299)

(12) OBJECT-ORIENTED

alléloisin ereídousai RECP.DAT.PL pile:PTPC.PRS.NOM.PL.F

'(First they carried the corpses, and put them under the portico of the well-fenced courtyard), piling (them) against each other.' (Od. 22.450) 
It must be remarked that in Homeric Greek the identification of subject-oriented direct reciprocals, i.e. those in which reciprocalization operates between the subject and the direct object, is not a trivial task. Specifically, the occurrence of the accusative case does not suffice as an indicator of direct objecthood, since many verbs in Homer take non-accusative direct objects (Sausa 2015). For this reason, one should consider as instantiating a subject-oriented direct reciprocal not only verbs that take an accusative direct object, such as enarizō 'slaughter' in (13), but also those verbs that take a genitive or a dative second argument, such as hamartánō 'miss' in (14) and amúnō 'protect' in (15) respectively (on the use of the dative case, see more diffusely Conti 2006).

(13) Direct: Nominative - AcCusative

amphì pólin Kaludôna kaì allélous enárizon

around city(F):ACC K.(F):ACC and RECP.ACC.PL slaugther:IMPF.3PL

'And they slaughtered one another about the city of Kalydon.' (Il. 9.530)

(14) DiRECT: NominAtive - GeNITIVE

égkhesi mèn gàr émbroton allêllōn

spear:DAT.PL PTC for miss:AOR.3PL RECP.GEN.PL

'Since they with their spear-throws had missed one other.' (Il. 16.335-336)

(15) DiRect: Nominative - DATIVE

eíken hoì hèmeîs otrunồmeth' amunémen

if PTC DEM.NOM.PL other:NOM.PL 1PL.NOM stir:SBJV.PRS.1PL.M/P defend:INF.PRS

allélloisin

RECP.DAT.PL

'If the others of us can stir ourselves up to defend each other.' (Il. 14.369)

Note further that there are several cases in which the argumental status of the second participant is unclear (cf. fn. 10). Especially when the second participant is encoded in the dative case and its 
argumenthood is doubtful, the passage could either be classified as subject-oriented direct, as indirect (with an omitted direct object), or as adverbial, as in the case of example (16). Each of these cases has been judged on its own, based on a combination of syntactic and contextual cues.

\author{
(16) toì d' allếloisi kéleuon \\ DEM.NOM.PL PTC RECP.DAT.PL shout:IMPF.3PL
}

'And the men were shouting to one another.' (Il. 2.151)

\title{
3.2.5. Semantics
}

As remarked in Section 2 and 3.1, RCs can encode semantically quite diverse situation types, based on the number of participants involved, their relationship, and the temporal unfolding of the event. In our analysis, we focused on two parameters, and looked at how reciprocal relationships encoded by allélōn distribute in terms of situation types and in terms of temporal unfolding.

As the analysis of the corpus shows, allêlōn covers all five situation types introduced in Section 3.1 , that is, it can express binary, unary, strong, weak, and chaining reciprocals. The various situation types are illustrated in examples from (17) to (19) (an example of weak reciprocal can be found in (16)). Moreover, the pronoun is not particularly sensitive to temporality, as it evenly occurs in contexts in which the reciprocal relationship is simultaneous, as in (19), and those in which the two sub-events take place in a temporal sequence, as in (17).

(17) BINARY, SEQUENTIAL

kaì allếlous eréoimen

and RECP.ACC.PL ask:PRS.OPT.1PL

'And we would question each other.' (Od. 4.192)

(18) UNARY

tò̀ en Messếnēi xumblètēen alléloï̀n 
DEM.DU.NOM PTC in M:DAT meet:AOR.3DU RECP.DAT.DU

'The two had met each other in Messene.' (Od. 21.15)

(19) Strong, SimultaneOUS

ou gár t' agnôtes theoì allếloisi pélontai

NEG for PTC unknown:NOM.PL.M god(M):NOM.PL RECP.DAT.PL be:PRS.3PL.M/P

'For gods are not unknown to each other.' (Od. 5.79)

(20) CHAINING

ōrkhê̂nt' allếlōn epì karpôi kheîras ékhontes

dance:IMPF.3PL.M/P RECP.GEN.PL on wrist:DAT hand:ACC.PL have:PTCP.PRS.NOM.PL 'They (young men and young girls) danced, and holding each other's hands at the wrist.' (Il. 18.594)

\subsection{Verbal voice}

As is well-known, the AG verbal system features a morphological two-fold opposition between active and middle inflections encoded by two distinct sets of endings (cf. e.g. Schwyzer \& Debrunner 1950: 216-241). Only the aorist and the future subsystems feature a distinct passive paradigm formed with the suffixes -ē- and -the- (cf. Chantraine 1953: 175; Magni 2010; Luraghi et al. forthc. for discussion with up-to-date references).

In Homeric Greek, it has been observed that most verbs occur only in either voices, that is, they belong either to the activa or the media tantum (on the semantics of the media tantum, see Delbrück 1897 and Allan 2003 for a more recent reappraisal). Only with a relatively few predicates do active and middle forms of the same verb stand in a functional opposition. When this is the case, middle forms generally function as a means to encode various valency changing operations, including passive, reflexive (direct and indirect), anticausative, and reciprocal (Allan 2003; Romagno 2010; for a typological definition of these functions and their features, see e.g. Creissels 2006 and Kulikov 2013). In this section, we focus on the role of the middle voice in encoding reciprocity. 
In Homer, out of a total of 1119 verbs that occur in the middle voice, only 80 are associated with reciprocal semantics, for a total of 672 tokens. We explore these verbs based on three main parameters: (i) their semantics in terms of proper vs. spatial (Table 4 vs. Table 5); (ii) the verbs' syntactic transitivity (first column in both tables); (iii) their relationship with verbal voice (secondfourth columns in both tables). Quantitative data on these parameters is summarized in Tables 4 and 5. We return on the interplay of middle reciprocals and the parameters of situation type and temporality more diffusely in Section 4.

Table 4: Proper reciprocal middle verbs

\begin{tabular}{|l|l|l|l|}
\hline \multicolumn{3}{|l|}{ Proper reciprocals } \\
\hline & \multicolumn{3}{l|}{ VOICE } \\
\hline SYNTAX & MT & A=M & OPPOSITIONAL \\
\hline INTR. & 11 & 2 & 2 \\
\hline TR. & 1 & - & - \\
\hline TOT & 16 & & \\
\hline
\end{tabular}

Table 5: Spatial reciprocal middle verbs

\begin{tabular}{|l|l|l|l|}
\hline \multicolumn{3}{|l|}{ Spatial reciprocals } \\
\hline & \multicolumn{2}{l|}{ VOICE } \\
\hline SYNTAX & MT & A=M & OPPOSITIONAL \\
\hline INTR. & 26 & 4 & 22 \\
\hline TR. & 5 & 7 & - \\
\hline TOT & 64 & & \\
\hline
\end{tabular}

Data extracted from the corpus shows that middle verbs with reciprocal interpretation mostly display intransitive syntax (67 intransitives vs. 13 transitives), and that most of these verbs indicate reciprocal relationships of the spatial type (16 proper vs. 64 spatial). Concerning their relationship with verbal voice, middle reciprocal verbs can be sorted out in three groups: those that only inflect in the middle voice, i.e. the media tantum (MT), those that attest to both active and middle forms without a detectable functional motivation $(\mathrm{A}=\mathrm{M})$, and those verbs whose middle forms stand in a functional opposition of sorts with active forms. In Sections 3.3.1-3.3.3, we discuss each of these groups in more detail, and in Section 3.3.4, we return to the syntactic constructions these verbs are involved in.

\subsubsection{Media tantum}


Out of 80 middle verbs associated with reciprocal semantics, 43 belong to the media tantum, i.e. they exclusively inflect in the middle voice. Note that for many of these verbs, this classification applies to Homeric Greek only, since many also display active forms in post-HG (cf. Schwyzer \& Debrunner 1950: 228). Verbs that belong to this group are consistently lexical reciprocals, and include both proper reciprocals, e.g. mákhomai 'fight' and isóomai 'be equal', as well as spatial reciprocals, e.g. ègeréthomai 'gather', aposkidnamai 'scatter', ántomai 'meet', and hépomai 'follow' (cf. already Conti 2006: 171). For the largest part (37/43), these verbs display intransitive syntax, and they are as such subject-oriented. As a representative example of this class, consider the intransitive syntax of the proper verb mákhomai 'fight' in (21) (we return on the syntax of this verb more diffusely in Section 3.2.4), and of the spatial verb ègeréthomai 'gather' in (22).

(21) kaì gàr egòn Akhileús te makhessámeth' heíneka koûrēs and for 1SG.NOM A.:NOM and fight:AOR.1PL.MID for girl:GEN antibiois epéessin opposing:DAT.PL.N $\quad$ word(N):DAT.PL

'For I and Achilles fought together for a girl's sake in words' violent encounter.' (Il. 2.377-8)

(22) amphi dé $\min$ Krētôn agoì ègeréthontai around PTC 3SG.ACC K.:GEN.PL lord:NOM.PL gather:PRS.3PL.M/P 'The lords of Krete gather about him.' (Il. 3.231)

The existence of media tantum that lexicalize inherently reciprocal events is not entirely surprising, as similar verbs are attested in other ancient IE languages as well. However, in IE languages the association of inherently reciprocal situations with the middle voice is far from being systematic. Indeed, if one looks at the distribution of lexical reciprocals in ancient IE languages, a partly idiosyncratic picture emerges, whereby these verbs' voice assignment cannot be simply 
predicted based on their semantics. Specifically, many lexical reciprocals also occur as activa tantum. This also holds true for Homeric Greek, where one finds the formulaic expression polemizein èdè mákhesthai 'to battle and fight' (e.g. Il. 2.212), where two nearly synonymous verbs display active and middle voice respectively (the same pattern recurs also in e.g. Latin proelior:MID vs. contendo:ACT 'fight' and Hittite zahhiya- ${ }^{\text {tta(ri) }}$ :MID vs. hulhuliya- ${ }^{z i}$ :ACT 'wrestle'; on active lexical reciprocals in AG, see more diffusely Conti 2006).

Note that a few transitive object-oriented reciprocals also exist, either spatial, e.g. katamáomai 'gather (tr.)' in (23), or proper, e.g. diaskopiáomai 'distinguish', but as data in Tables 4 and 5 shows, these clearly constitute a minority. The reason why these verbs inflect in the middle voice is not clear altogether, but need not concern us here, since it appears that these verbs' association with the middle voice has little to do with their spatial reciprocal semantics. At any rate, the existence of transitive media tantum is a well-known phenomenon, as verbs of this type do occur in most ancient IE languages and can be even reconstructed to some extent for PIE (cf. Grestenberger 2016).

\author{
(23) $t \overline{e ́ n}$ \\ hra kulindómenos \\ katamè́sato \\ khersin \\ DEM.ACC PTC roll:PTCP.PRS.NOM.M/P gather:AOR.3SG.MID hand(F):DAT.PL \\ heêisi \\ POSS.3SG.DAT.PL.F
}

'For he had been rolling in it (i.e. dung) and gathered it with his own hands.' (Il. 24.165)

\title{
3.3.2. Verbs that display functionally identical active and middle forms
}

In Homer, only 13 reciprocal verbs out of 80 display functionally identical active forms beside middle ones. These verbs include lexical reciprocals of both the proper and spatial types. Proper reciprocals of this class are all intransitive and subject-oriented, e.g. eridaínō 'quarrel' and erízō 'quarrel', whereas spatial verbs include both intransitive subject-oriented, e.g. sunantáo 'meet', and transitive 
object-oriented reciprocals, i.e. keránnumi 'mix (tr.)'. With these verbs, voice alternation does not apparently affect the verb's valency. Compare middle and active forms of erizō 'quarrel' with identical syntax and semantics in $(24) a-b .{ }^{11}$

(24) a. MIDDLE

$\begin{array}{lllll}\text { hôi } \quad \text { oú tís } & \text { toi } & \text { erízetai } & \text { entháde g' } \\ \text { REL.DAT NEG INDF.NOM.M } & \text { 2SG.DAT } & \text { contend:PRS.3SG.M/P } & \text { here PTC } \\ \text { anếr } & & & & \\ \text { man(M):NOM } & & & & \end{array}$

'(The fame) in which no man here contends with you.' (Il. 5.172)

b. ACTIVE

\begin{tabular}{|c|c|c|c|c|c|}
\hline$h \bar{o}$ & $t^{\prime}$ & olígōi & eni & khốrōi & erízēton \\
\hline DEM.DU.NOM & PTC & small:DAT.M & in & place(M):DAT & contend:PRS.3DU around \\
\hline$i ́ s \bar{s} s$ & & & & & \\
\hline
\end{tabular}

'And the two fight in the strait place over the rights of division.' (Il. 12.423)

It is not easy to determine the original inflection of these verbs, and each should be judged on its own. In some cases, reasonable hypotheses concerning these verbs' voice selection can be formulated. For example, active forms of eridaínō and erizō 'quarrel' show a higher token frequency as compared to middle ones, thus suggesting that these verbs were activa tantum to begin with (both verbs are denominatives from éris, idos 'strife, quarrel', cf. DELG 372). The verb sunantáō 'meet' offers a similar scenario: since this verb is based on active antáo (itself derived from ánta 'over against, face to face', cf. DELG 91-92), its middle voice is possibly a later trait. With the few object-oriented

\footnotetext{
${ }^{11}$ Note that in examples (24)a-b above the active-middle selection cannot be boiled down to metrical factors: both the active and the middle forms would have fitted the meter in both passages.
} 
transitive verbs, the middle voice has little to do with the reciprocal semantics, as it can sometimes be explained as expressing indirect middle semantics in the sense of Kemmer (1993: 78-81), i.e. as indicating that the subject performs the action on its own benefit. This is possibly the case of datéomai 'divide', which often acquires the meaning 'divide among themselves' when used with a plural subject.

\subsubsection{Oppositional middle verbs}

As mentioned above, oppositional middle verbs are those that show a systematic syntactic and semantic opposition to the corresponding active forms. Within the group of reciprocal verbs, there are only two such verbs that belong to the proper type, i.e. outázō 'stab, wound' and ameibo 'change, alternate'. Since the two differ in their behavior, we thoroughly discuss both of them. Let us begin by considering the verb outázō 'stab, wound', as in (25).

a. ACTIVE: NON-RECIPROCAL

$\begin{array}{lllll}\text { étoi } & \text { Tudéos huiòs } & \text { Agástrophon oútase } & \text { dourì } \\ \text { ADV } & \text { T.:NOM son:NOM } & \text { A.:ACC } & \text { wound:AOR.3SG } & \text { spear:DAT }\end{array}$

'Now Tydeus' son stabbed with the spear Agastrophos.' (Il. 11.338)

b. MIDDLE: RECIPROCAL

kaí nú ke dè xiféess' autoskhedòn outázonto

and now PTC PTC sword:DAT.PL hand.to.hand wound:PRS.3PL.M/P

'And now they would have been stabbing each other with their swords at close quarters.' (Il. 7.273)

In (25)a, the active verb oútase 'stabbed' is used in a transitive construction with the nominative subject huiòs 'son (of Tydeus)' and the accusative direct object Agástrophon 'Agastrophos', and the two participants are involved in an asymmetric non-reciprocal situation, with the subject performing 
the semantic role of agent and the object that of patient. Conversely, in (25)b the verb occurs in the middle voice, is used intransitively, and it indicates a reciprocal situation, in which both participants perform the role of agent and patient. This is to our knowledge the only Homeric case in which the middle voice operates as a marker of a grammatical reciprocal, in that it triggers a reciprocal interpretation of an otherwise non-inherently reciprocal verb. Notably, middle forms with plural subjects of outázō are by no means systematically associated with reciprocity, since they most often have passive meaning 'wounded' (cf. Il. 12.427). In this respect, it is worth observing that the reciprocal reading in (25)b is also reinforced by the adverb autoskhedón 'hand to hand, in close fight'.

The verb ameíbō 'change, alternate' offers a different scenario, as shown in (26)a.

(26) a. ACTIVE: RECIPROCAL OBJECT-ORIENTED

stàs d' apáneuthe mákhēs poludakrúou
stand:PTCP.AOR.NOM PTC apart fight(F):GEN sorrowful:GEN.F
énte' ámeiben
armour:ACC.PL change:IMPF.3SG

'He stood apart from the sorrowful fight, and changed his armor.' (Il. 17.192)

b. MIDDLE: RECIPROCAL SUBJECT-ORIENTED

nôi mèn hò̀s epéeessin ameibómeth’

1DU.NOM PTC thus word:DAT.PL change:IMPF.1PL.M/P

'So the two of us exchanged words (lit. alternate with words).' (Od. 11.225)

As comparison between (26)a and (26)b shows, in the active voice the verb ameíbo is used transitively and indicates an object-oriented reciprocal event 'change, replace (smth. with smth. else)'. By contrast, in the middle voice the verb is used intransitively to indicate a subject-oriented reciprocal 
situation of the chaining type 'change with one another, alternate'. ${ }^{12}$ In this respect, ameíbo displays a syntactic behavior similar to outázō, with active forms showing transitive and middle forms showing intransitive syntax respectively. However, the two verbs differ in that ameíbo 'replace, change' is an inherently reciprocal predicate, whereas outázo 'stab' is not, so that only with the latter can the middle voice be regarded as being responsible for the reciprocal interpretation of the event.

Besides the two proper reciprocals, the largest part (22/24) of the oppositional group is made up by inherently reciprocal verbs of the spatial type, chiefly verbs of 'joining' and 'splitting' (Knjazev 2007), e.g. ageírō 'gather' and mígnumi 'mix'. With these verbs, active forms consistently indicate an object-oriented situation and are used transitively, as shown in (27):

(27) ACTIVE: RECIPROCAL OBJECT-ORIENTED

a. es d' erétas epitēdès ageíromen

for PTC rower:ACC.PL enough gather:SBJV.AOR.1PL

'And assemble rowers enough for it.' (Il. 1.142)

b. hoi mèn ár' hoînon émisgon enì krētêrsi kaì DEM.NOM.PL PTC PTC wine:ACC mix:IMPF.3PL in bowl:DAT.PL and húdōr

water:ACC

'Some who mixed wine and water in mixing bowls.' (Od 1.110)

Middle forms of these verbs systematically provide the intransitive and subject-oriented counterpart to active object-oriented verbs. Compare in this respect active forms of ageirō 'gather' and mignumi 'mix' in (27) with their corresponding middle forms in (28)a and (28)c. Middle forms

\footnotetext{
${ }^{12}$ Note that in the middle voice, the reciprocal semantics only emerges when the verb inflects in the plural, since in the singular the verb specialized in the non-reciprocal meaning 'alternate with words $>$ answer' within formulaic expressions (see De Decker 2015: 172-192 for a full discussion).
} 
of spatial reciprocals can either have an anticausative or a passive reading, depending on the context and the features of the participants (cf. Nedjalkov 2007a: 91 on anticausative reciprocals). In (28)a, the middle form agéronto 'gathered' indicates a situation agentively carried out by the subject participant without an intervening external force, and can be thus interpreted as an anticausative verb of the autocausative type (on the autocausative vs. decausative distinction see also Haspelmath 1987; Creissels 2006: 10; Haspelmath 2016; on the role of the middle voice for the encoding of the anticausative alternation in Homeric Greek, see i.a. Sausa 2016 with references). The middle participle agroménoisi (28)b instead refers to an event triggered by an external agent but constructed from the perspective of the patient súessi, which is syntactically the head of the participle, hence the interpretation of this form as a true passive.

(28) MidDlE: PASSIVE OR ANTICAUSATIVE SUBJECT-ORIENTED

a. hai agéronto psukaì upèx Erébeus

DEM.NOM.PL.F PTC gather:AOR.3PL.MID soul(F):NOM out.from.under E.:GEN nekúōn katatethnēōtōon

$\operatorname{dead}(\mathrm{M})$ :GEN.PL die:PTCP.PRF.GEN.PL.M

'Up out of Erebus they gathered, the souls of the dead.' (Od. 11.36-7)

b. ékpempsán te nomêas hám' agroménoisi

send.out:AOR.3PL PTC herdsman:ACC.PL together gather:PTCP.AOR.MID.DAT.PL.M súessi

$\operatorname{pig}(\mathrm{M}): \mathrm{DAT} . \mathrm{PL}$

'And sent out the herdsmen with the pigs that had been gathered.' (Od. 16.3)

c. hé $t^{\prime}$ aékēti phílōn patròs kaì

REL.NOM.F PTC against.one's.will dear:GEN.PL.M/F father(M):GEN and

mētròs eóntōn andrási mísgētai

mother(F):GEN be:PTCP.PRS.NOM.PL man:DAT.PL mix:SBJV.PRS.3SG.M/P 
'(I) who, while her dear father and mother are alive, against their will mixes with men.' (Od. 6.287-8)

It is worth observing that the neat picture outlined so far, whereby active forms of spatial reciprocals are associated with transitive syntax and middle forms with intransitive syntax is partly blurred by the existence of sporadic middle labile verbs, i.e. verbs that alternate between transitive and intransitive syntax without displaying a change in form (see Kulikov 2014b; for a detailed account of lability in the history of Greek see further Karantzola \& Lavidas 2014 with references). A case in point is the verb légō, whose middle forms can either mean 'collect (tr.)' (cf. Il. 8.507) or 'gather (intr.)' (cf. Il. 13.276).

\subsubsection{Constructions of middle reciprocal verbs}

In Sections 3.3.1-3.3.3, we have shown that middle reciprocals are mostly intransitive and subjectoriented, even though transitive object-oriented ones exist as well. A closer look at the corpus however reveals that the two-fold transitive vs. intransitive distinction is somewhat too simplistic and does not easily account for the entirety of the data. In fact, the syntax of these verbs shows a more complex picture. Middle reciprocal verbs show up in at least three constructions (cf. Conti 2006). As discussed in Section 3.1, based on the syntactic encoding of the two reciprocants, one can distinguish between simple, discontinuous, and absolute constructions (cf. Nedjalkov 2007a: 27).

In simple constructions, the two reciprocants are assigned the same syntactic role. For example, with subject-oriented simple reciprocals, the two reciprocants are encoded by a plural subject or by two coordinated subject NPs. As an example, consider the construction of the verb márnamai 'fight' in (29), whose participants are encoded by plural álloi 'the rest'.
(29) $h o i$
d' álloi
márnanto
DEM.NOM.PL.M PTC other:NOM.PL.M fight:IMPF.3PL.M/P 
'But the rest fought on.' (Il. 13.540)

Discontinuous constructions are characterized by the occurrence of one reciprocant in argument position, whereas the second one is encoded as an oblique, often a comitative expressed in the dative case. One such example is the construction in which márnamai 'fight' occurs in (30).

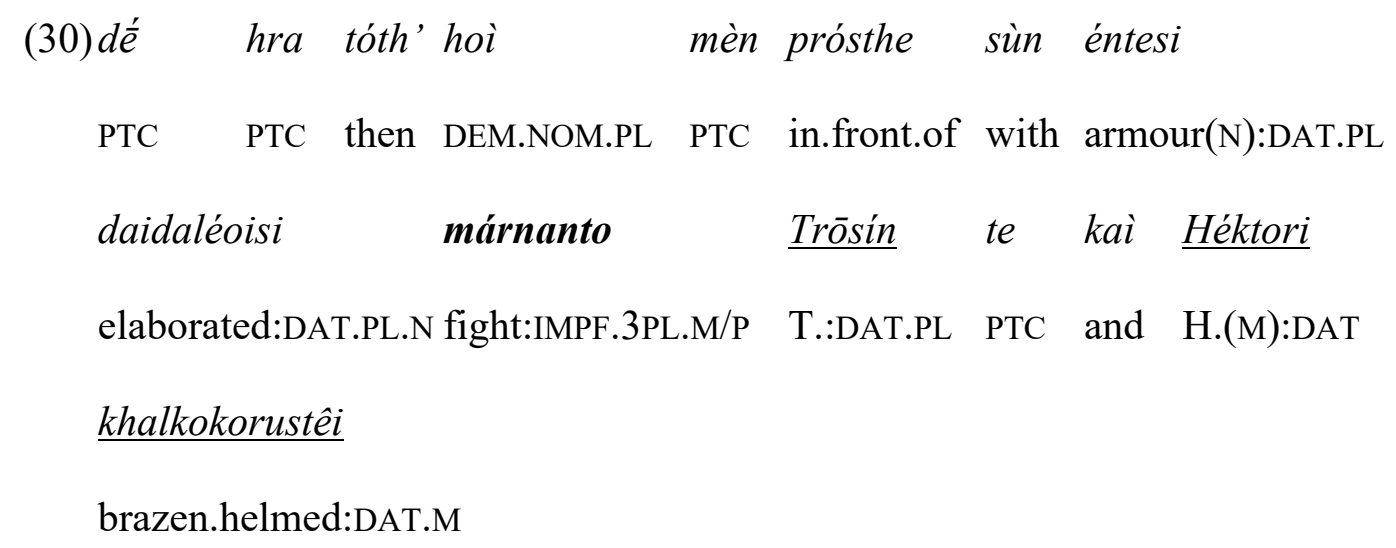

'So now these others fought in front in elaborate war gear against the Trojans and Hektor the brazen-helmed.' (Il. 13.720)

In example (30), the first reciprocant is encoded by the nominative pronoun hoi 'these' in subject position, whereas the second reciprocant is expressed by the dative NPs Trōsín te kaì Héktori khalkokorustêi. In contexts with discontinuous constructions, HG tends to encode the second reciprocant in the dative case, consistently with the use of the dative with reference to human participants, especially with verbs of social interaction (cf. Conti 2006; Sausa 2015: 108-109, 374377; on the competition between the prepositionless and the prepositional dative in later Greek, see the discussion in Conti 2006).

Finally, we define absolute constructions as those in which only one reciprocant in a reciprocal situation is overtly expressed, whereas the second one is left implicit altogether. However, as these are inherently reciprocal verbs, the latter reciprocant is clearly entailed in the verb's lexical 
semantics. ${ }^{13}$ This construction is exemplified in (31), where only one participant of the event expressed by márnamai is encoded, and no mention is made of the second participant.
(31)epei hra mákhēs
ep' aristerà márnato
pásēs
since PTC battle(F):GEN on left:ACC fight:IMPF.3SG.M/P all:GEN.F

'Since he was fighting at the left of the entire battle.' (Il. 11.498)

As the comparison among examples (29)-(31) shows, the very same verb can occur in all three constructions. The difference among these is essentially one of construal, whereby within the same inherently reciprocal situation speakers can chose to profile either reciprocant as more or less agentively involved in the event (cf. Allan 2003: 62-53; on the notions of construal and profile, cf. e.g. Croft \& Cruse 2004: esp. 40-73). As shown in Table 6, individual verbs display different preferences for each construction, and the choice is not entirely predictable from the verbs' semantics. For instance, whereas mákhomai 'fight' shows a strong preference for the absolute construal, this is not the case of the semantically similar verb márnamai 'fight', which is more evenly distributed across the three constructions. For reasons of space, in Table 6 we only discuss the syntax of proper middle reciprocals, but similar considerations also hold for spatial ones. For example, the verb ageírō 'gather' always occur in a simple construction, whereas the verb mígnumi 'mix' occurs predominantly in the discontinuous construction (50/67 tokens), and only marginally in the simple (10/67) and absolute (7/67) constructions.

Table 6: Constructions of proper reciprocal middle verbs

\footnotetext{
${ }^{13}$ Note that such cases are to be kept distinct from null referential objects mentioned at fn. 9. Here, a verb that encodes an event involving at least two participants in the reality is used intransitively. With null referential objects, by contrast, a zero anaphora is employed to specifically refer back to a previously mentioned participant; thus, the verb cannot be said to be employed intransitively (cf. Luraghi 2003a).
} 


\begin{tabular}{|c|c|c|c|c|}
\hline \multirow[b]{2}{*}{ Verb } & \multicolumn{3}{|c|}{ Construction } & \multirow[b]{2}{*}{ Total $N$} \\
\hline & Simple & Discontinuous & Absolute & \\
\hline amphimákhomai 'fight around' & 2 & - & 6 & 8 \\
\hline dèriáomai 'contend' & 7 & - & - & 7 \\
\hline isóomai 'be equal' & - & 1 & - & 1 \\
\hline márnamai 'fight' & 20 & 12 & 24 & 56 \\
\hline mákhomai 'fight' & 37 & 87 & 122 & 246 \\
\hline okriáomai 'quarrel' & 1 & $1-$ & - & 1 \\
\hline homoióó 'be equal' & - & 2 & - & 2 \\
\hline homoómai 'meet' & 1 & - & - & 1 \\
\hline plēktízomai 'contend' & I- & 1 & - & 1 \\
\hline promákhomai 'fight' & - & - & 2 & 2 \\
\hline summētiáomai 'consult' & 1 & - & - & 1 \\
\hline eridaínō ‘quarrel' & $I_{-}$ & 1 & & 1 mid. \\
\hline erízō'quarrel' & & 2 & & 2 mid. \\
\hline ameíbō 'change, alternate' & 9 & | & 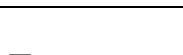 & 9 mid. \\
\hline
\end{tabular}

\subsection{Reciprocal constructions with preverbs}

Preverbs make up a class of uninflected morphemes that occur in front of a verb, whose primary function is to modify the verb's meaning by adding spatial information or by turning its lexical aspect from durative to punctual or from atelic to telic (Zanchi forthc.: Section 3.1.1 with references). Preverb+verb combinations can also result in idiosyncratic or lexicalized meanings, which cannot be predicted from the combination of preverbs' original spatial semantics and verbs' meaning (e.g. AG ep-ana-tithèmi 'on-upward-put' $\rightarrow$ 'shut'). ${ }^{14}$ To put it differently, preverbs' diverse semantic

\footnotetext{
${ }^{14}$ Preverbs are accompanied by their etymological meaning in this paper.
} 
contributions can only partly be assumed from preverbs' etymological spatial meanings: instead, they are crucially related to the semantics of the verbs onto which preverbs attach and to the wider sentence context (cf. in particular Section 3.4.2).

In a number of ancient IE languages, including Homeric Greek, preverbs enjoy considerable syntactic freedom. Specifically, besides occupying the preverbal position, the very same array of uninflected morphemes may occur in other placements: in the so-called absolute position, functioning as quasi-predicates, thus supplying the function of an omitted present copula; before or after a noun, virtually functioning as pre- or post-positions; in any other position within the sentence as freestanding adverbs (cf. Chantraine 1953: 82; Watkins 1964; Cuzzolin et al. 2006; Zanchi forthc.: Section 3.1.2. with references). Such positional freedom results into a great deal of uncertainty as regards preverbs' morphological status (clitics vs. independent words) and their part of speech (freestanding adverbs, adpositions, or preverbs proper). This complex picture is further complicated by the fact that preverbs can also occur displaced from the verb that they modify, despite retaining semantic cohesion with it. This "split" is traditionally called tmesis (on the significance of tmesis for the diachrony of AG and IE preverbs, cf. Zanchi forthc.: Section 3.1.2-3.1.3 with references).

Besides the outlined semantic function, IE preverbs are also acknowledged to be connected with valency-related operations. For example, owing to the well-known link among telicity, perfectivity, and transitivity (cf. i.a. Hopper and Thompson 1980), preverbs can occasionally promote a peripheral argument or adjunct to a core argument status (on the so-called applicative function of preverbs, cf. Zanchi forthc.; on Vedic, Danesi 2009; Kulikov 2012; on AG, Horrocks 1981; Viti 2008). Importantly for the aims of this paper, previous scholars assigned to IE and AG preverbs the ability to occur in RCs (cf. Kulikov 2007 on Vedic; Nedjalkov et al. 2007: passim on AG, Latin, and Sanskrit.; Revuelta 2007 on AG sun- 'with', Revuelta 2015 on Latin com- 'with', Revuelta 2017 on Latin dis- 'in two parts'; Zaliznjak \& Shmelev 2007 on Latin com- 'with'; Dedio \& Widmer 2017 with references on OIr. and MIr. imm-( $\left.a^{-}{ }^{N}\right)-$ 'on both sides'; Inglese 2017 on Hittite preverbs and local particles). In the remainder of this section, we argue that in Homer the link between preverbs and the encoding of 
reciprocity is still a tenuous one, and the development of full-fledged reciprocal preverbs is possibly a post-HG trait (see further Section 5). Thus, the development of the reciprocal function with preverbs chronologically fits the larger picture of the other grammatical functions associated with AG preverbs, which are still at their onset in Homer (Zanchi forthc.: Ch. 5).

In Homer, preverbs contribute to forming 33 verbal lemmas (type-frequency) that can have a reciprocal meaning, for a total of 103 occurrences expressing reciprocal situations (token-frequency). Importantly, given that Homeric preverbs do not function as grammatical reciprocal markers and given that preverbs and consequently compound verbs are highly polysemous items, not all attested occurrences of the above lemmas serve to encode reciprocal situations (reciprocal events are expressed in 103/210 passages attesting to these 33 lemmas). In Homeric Greek, only six preverbs (out of 19) are employed in RCs. These are displayed in Table 7, together with their type-frequencies (“Verbal Lemmas") and one example; references to preverbs' etymologies are also provided, given that the latter can be relevant for their subsequent development into reciprocal markers (cf. Section $5)$.

In Sections 3.4.1-3.4.4, after touching upon the topic of preverbs' polysemy and explaining how this connects with the difficulties in distinguishing RCs with preverbs, we analyze the parameters that we acknowledged as relevant for preverbs' distribution in the reciprocal domain. These include the semantics of the verbal bases onto which preverbs attach, the semantics of the whole reciprocal situation, and the constructions in which the reciprocal compounds occur.

Table 7: AG preverbs attested in RCs

\begin{tabular}{|l|c|l|l|}
\hline Preverb 'etymological meaning' & Verbal & Example & Simplex verbs' \\
\hline $\begin{array}{l}\text { amphi- 'on both sides' } \\
(D E L G ~ 80, L I P P ~ 35-40)\end{array}$ & 3 & amphi-épō 'crowd about' & hépomai 'follow' \\
\hline anti- 'in front of' & 3 & anti-boléó 'meet' & boléo 'throw' \\
\hline
\end{tabular}




\begin{tabular}{|c|c|c|c|}
\hline (DELG 91-92, LIPP 306-311) & & & \\
\hline $\begin{array}{l}\text { dia- 'in two directions' } \\
(D E L G 276, L I P P \text { 145-147) }\end{array}$ & 6 & $\begin{array}{l}\text { di-airéō } \\
\text { 'take apart, divide' }\end{array}$ & hairéó 'take' \\
\hline $\begin{array}{l}\text { epi- ‘on' } \\
(D E L G 358, L I P P 245)\end{array}$ & 2 & epi-mísgō 'mix with' & mísgō 'mix' \\
\hline $\begin{array}{l}\text { meta- 'in the middle of' } \\
(D E L G 689, L I P P 494-501)\end{array}$ & 1 & met-histēmi 'exchange' & histèmi 'stand' \\
\hline $\begin{array}{l}\text { sun- 'with' } \\
\text { (DELG 767, LIPP 717-729; Neri 2013) }\end{array}$ & 18 & sunistēmi 'meet' & histēmi 'stand' \\
\hline
\end{tabular}

\subsubsection{Preverbs' polysemy: the difficult task of distinguishing reciprocal preverbs}

Given the high polysemy of preverbs, it is not always straightforward to keep the reciprocal meaning distinct from semantically related ones. As Nedjalkov (2007a: 39) already remarked, for example, the AG preverb sun- contained in sum-phéro (here, its allomorph sum-occurs) is instructive in this respect: depending on the context, it may be liable to an assistive 'help smbd. carry smth.', sociative 'carry smth. together with smbd.', comitative 'carry smth. with smbd.', and spatial reciprocal 'bring together' reading. This also holds true for sun-déó 'tie together', which contains the lexical reciprocal simplex verb déo 'tie', as shown by the comparison between examples (32) and (33).

(32) SOCIATIVE READING

hoppóte min xundêsai Olúmpioi éthelon álloi

when 3SG.ACC bind:INF.AOR O.:NOM.PL.M want:IMPF.3PL other:NOM.PL.M

'That time when, all together, the other Olympians sought to tie him...' (Il. 1.399)

(33) RECIPROCAL READING

sunédēsa pódas deinô̂o pelórou

bind:AOR.1SG foot:ACC.PL deard:GEN.N monster(N):GEN

'I tied the feet of the dread monster together.' (Od. 10.168) 
In (32), a plural subject, Olúmpioi...álloi '(the) other Olympians', coordinates their effort at the expense of a third participant, min 'him' (i.e. Zeus). The preverb sun- (here, its allomorph $x$ un- occurs) means 'cooperatively', and highlights the fact that the Olympians are carrying out a collaborative task: thus, it expresses a sociative meaning. Instead, in (33), an object-oriented reciprocal situation is described, in which a first person singular subject is acting over the object reciprocants pódas 'feet'; here the preverb sun- strengthens the inherently reciprocal spatial meaning of the simplex verb déo ${ }^{15}$

Similarly, in sum-phrázomai 'consider together with', the preverb sun-per se triggers more of a sociative than of a reciprocal meaning, as suggested by comparing the passages in (34) and in (35).

(34) SOCIATIVE

\begin{tabular}{lll} 
idoûs & \multicolumn{1}{c}{ hóti hoi } & sumphrássato \\
see:PTCP.AOR.NOM.F & that 3 SG.DAT & consider.together.with:AOR.3SG.MID \\
boulàs & argurópeza & Thétis \\
counsel:ACC.PL & silver.footed:NOM.F & T.(F):NOM
\end{tabular}

'Having seen how Thetis the silver-footed had been plotting counsels together with him [and at the expenses of a third one].' (Il. 1.536-537)

(35)RECIPROCAL (with a reciprocal pronoun)

allà kakà phronéousi diamperès allếloisin

but bad:ACC.PL think:PRS.3PL forever RECP.DAT.PL

'But forever these hold feelings of hate for each other.' (Il. 22.264)

\footnotetext{
${ }^{15}$ It is often the case that preverbs show a high degree of semantic solidarity with the verbal bases upon which they attach. In Zanchi (forthc.: Ch. 8), such solidarity is regarded as one of the main reasons for their eventual lexicalization and grammaticalization (cf. below Section 3.4.3).
} 
Example (34) contains the putative reciprocal compound under discussion, that is, sum-phrázomai 'consider together with, join in considering', whereas example (35) includes a RC with the simplex verb phronéo 'be minded, think' (possibly, etymologically related to phrázomai, cf. DELG 12241225; Beekes 2010: 1588, 1590-1591) and - crucially - the reciprocal pronoun. In both event types, two participants perform two identical semantic roles each, specifically experiencer in (34) and experiencer/stimulus in (35), but sociative participants of (34) perform an action toward a third event participant, who plays the role of stimulus, and lack the inverse semantic component typical of RCs and shown in (35) due to the occurrence of the reciprocal pronoun. ${ }^{16}$ Thus, in combination with phrázomai 'think', sun- cannot express reciprocity in our corpus, as instead does the reciprocal pronoun, which enjoys a much wider distribution and productivity as a reciprocal marker (cf. Section 4).

Another interesting case is the compound met-histēmi, which occurs only twice in the Homeric poems: in $O d .4 .162$, it means 'exchange', thus exhibiting a reciprocal semantics; by contrast, in $I l$. 5.514 , it signifies 'stand among (the others)'. This variation mirrors the polysemy of meta-: both as a preposition and as a preverb, this uninflected morpheme can mean 'among' (+GEN, DAT, ACC) and 'after' in a sequence $(+\mathrm{ACC})$. The latter meaning has arguably given rise to the reciprocal semantics of met-histèmi: 'stand one after the other' $\rightarrow$ 'exchange' (cf. Section 5 for further insights on the origins of preverbs' reciprocal meaning). In addition, one must distinguish preverbs that, with their semantic contribution, truly participate in making up a reciprocal compound, such as meta- 'after' in met-histèmi 'stand one after the other' $\rightarrow$ 'exchange', from preverbs that merely happen to occur in a RC, but having actually nothing to do with reciprocity. For example, the preverb hupo- 'under' in hupo-zeúgnumi 'yoke' is one such case: it simply strengthens the meaning of sub-mission as related to zeúgnumi 'yoke'; it is the verbal base itself that lexicalizes an object-reciprocal situation, namely that of yoking. Thus, here we can observe once more semantic solidarity between the preverb and the

\footnotetext{
${ }^{16}$ Our corpus attest to other examples relevant for this ambiguity, on which we do not focus here at length for reasons of space (see however the discussion below on sum-bállō).
} 
simplex verb, as with sun-déō above; in this case, however, the preverb's semantics are close to a subcomponent of the simplex verb's meaning unrelated with reciprocity.

Precisely because of the outlined intricate picture, we carefully scrutinized all the Homeric attestations of the 33 verbs that, among other meanings, attest to reciprocal semantics, in order to include in our study only the occurrences that actually express a reciprocal situation.

\subsubsection{Semantics of the verbal base}

As regards the semantics of simplex verbs onto which preverbs attach, data shows a clear prevalence (23 out of 33) of motion and location verbs (e.g. eimi 'go, come'), or of verbs that can be easily assimilated to them, including (i) caused motion verbs (e.g. bállō 'throw'), (ii) posture verbs (e.g. histèmi 'stand'), (iii) manner of motion verbs (e.g. trékhō 'run'), and (iv) verbs of putting and taking (e.g. hairéō 'take'), as displayed in Table 8. This is not at all surprising, given preverbs' original spatial semantics and, consequently, their overall tendency to combine with motion and location verbs in the earliest stages of IE (cf. Zanchi forthc: Section 4.2.2 and 5.2.2 with references, on Vedic and on Homeric Greek). Accordingly, compound verbs with reciprocal preverbs tend to occur in spatial reciprocal situations (cf. Section 3.4.3).

Table 8: Simplex verbs: their semantic types

\begin{tabular}{|c|l|c|}
\hline VERB TYPE & EXAMPLE & TYPE-FREQUENCY \\
\hline MOTION/LOCATION & \multicolumn{1}{|c|}{-} & 23 \\
\hline proper & eîmi 'go, come' & 7 \\
\hline caused motion & bállō 'throw' & 3 \\
\hline posture & hístēmi 'stand' & 2 \\
\hline manner of motion & trékhō'run' & 3 \\
\hline putting and taking & hairéó 'take' & \\
\hline
\end{tabular}




\begin{tabular}{|l|l|c|}
\hline OTHER & \multicolumn{1}{|c|}{-10} \\
\hline fighting & mákhomai 'fight' & 1 \\
\hline speech verbs & kaléō 'call' & 2 \\
\hline perception/cognition & skopéo 'look at, examine' & 2 \\
\hline splitting & tméggo (post-HG) ‘cut' & 2 \\
\hline joining & déō 'tie' & 3 \\
\hline
\end{tabular}

Other verb types include verbs indicating different kinds of social interactions, such as verbs of fighting (e.g. mákhomai 'fight') and speech verbs (e.g. kaléō 'call'), perception/cognition verbs (e.g. skopéō 'look at, examine'), and activity verbs expressing some sort of separation (e.g. tmégōo [postHG] 'cut') or unification (e.g. déo 'tie') (on verbal base classification, as relevant in relation to preverbs, cf. Zanchi forthc.: Section 5.2.2 with references).

Verb types include both inherently reciprocal bases (14/33 lemmas), such as mákhomai 'fight', déó 'tie' or ageirōo 'collect', and non-reciprocal ones (19/33 lemmas), such as kaléō 'call', skopéo 'look at, examine' or bállō 'throw'. With the former group, it is not always clear whether the preverb actually brings about reciprocal semantics, strengthens it, or adds a nuance of a different type instead, as thoroughly explained in Section 3.4.1. Instead, with other lexical reciprocal bases, preverbs reinforce the inherent reciprocal semantics: compare datéomai 'divide, separate' vs. dia-datéomai 'in two parts-divide' and ageírō 'gather' vs. sun-ageírō 'gather together'. Similar cases of semantic solidarity between a preverb and the modified verbal base are indeed common: in Slavic linguistics, this semantic solidarity is well-known and called Vey-Schooneveld effect or subsumption (cf. fn. 15, Zanchi forthc.: Ch. 6).

With non-reciprocal bases, the preverb is clearly responsible for the emergence of the reciprocal meaning, as the contrast between (36)a and (36)b shows (cf., with amphi-, example (37) below). In (36)b, the simplex verb kaléo 'call' is prefixed with sun- (here, its allomorph sug- occurs) and takes a plural object: the compound comes to express an object-oriented reciprocal situation. 
(36)a. ôkh' hekatógkheiron kalésas' es makròn Ólumpon quickly of.hundred.hands:ACC call:PTCP.AOR.NOM to high:ACC.M O.(M):ACC '...after quickly calling to high Olympus (him) of the hundred hands.' (Il. 1.402)

b. toùs hó ge sugkalésas pukinèn

DEM.ACC.PL 3SG.NOM.M PTC summon:PTCP.AOR.NOM.M sagacious:ACC.F artúneto boulén

arrange:IMPF.3SG.M/P counsel(F):ACC

'Summoning these, he arranged a sagacious counsel.' (Il. 2.55=10.302)

In the case of the kaléo 'call' vs. sug-kaléó 'summon' pair, a spatial reciprocal compound is built from a non-reciprocal simplex speech verb. This process is of a compositional nature: a new lexical item with reciprocal meaning is made up from a non-reciprocal simplex verb through an additional preverb.

Crucially, in Homeric Greek, the reciprocal meaning is not associated to the preverb per se yet; rather, it seems to emerge from the preverb-verb construction. To put it simply, Homeric preverbs do not function as grammatical reciprocal markers yet. This is clearly observable in example (37), where the preverb amphi- 'on both sides' occurs in tmesis position and manifests semantic cohesion with the final verb, héponth'(o) 'follow', resulting together in a RC: amphi...épō 'on both sides...follow' $\rightarrow$ 'on all sides...follow' $\rightarrow$ 'crowd about' (on the semantic development of amphi- 'on both sides' $\rightarrow$ 'on all sides', cf. Chantraine 1953: 129-130; Luraghi 2003b: 256; Zanchi forthc.: Section 5.4).

(37)RECIPROCAL MEANING EMERGING FROM THE PV ...VERB CONSTRUCTION amphì d' ár autòn Trôes héponth' on.both.sides PTC PTC DEM.ACC T.NOM.PL follow:IMPF.3PL.M/P Literally: 'The Trojans followed him from all sides.' 
'And around him the Trojans crowded.' (Il. 11.473)

\subsubsection{Semantics of the reciprocal situation}

Not surprisingly, given the predominance of motion/location verbal bases (Section 3.4.2), preverbs significantly tend to contribute to the encoding of spatial reciprocal situations (96/103 occurrences). The few proper reciprocal situations are expressed by a RC containing the following compounds: amphi-mákhomai 'fight around', amphi-bállō 'embrace', dia-krínō 'separate one from another', and ep-ameíbō 'exchange'. Out of these four, two, i.e. amphi-mákhomai 'fight around' and ep-ameíbō 'exchange' contain two inherently reciprocal bases.

Again, compound verbs, including the four just mentioned, are polysemous items, and as such can encode both proper and spatial reciprocal situations. The comparison between the following two Homeric occurrences with amphi-bállō 'embrace' contributing to a RC is of particular interest in this respect:

(38)PROPER RECIPROCAL

mínunthá per amphibalónte allélous

for.a.little.time PTC throw.around:PTCP.AOR.NOM.D RECP.ACC

'And, if only for a little, embraced, (let us take full satisfaction from the dirge of sorrow).' (Il. 23.97-98)

(39) SPATIAL RECIPROCAL

hốs hoi khềres ekhándanon amphibalónti

as.much.as 3SG.DAT.M hand:NOM.PL hold:IMPF.3PL throw.around:PTCP.AOR.DAT.M 'As much (bread and meat) as his hands could hold, when he threw (them, viz. his hands) around (it, viz. the amount of bread and meat).' (Od. 17.344) 
In (38), a compound with amphi- and, crucially, the reciprocal pronoun allélous contribute to building a RC encoding the proper reciprocal situation of 'embracing each other'. In (39), instead, without the reciprocal pronoun, the reciprocal situation remains of a spatial nature: Telemachus is described, in the act of holding, and thus of surrounding with his hands, the greatest quantity of bread and of meat that he can. Thus, the preverb amphi-per se seems to select spatial situation types.

The emergence of a proper reciprocal reading is highly context-dependent with compounds containing non-reciprocal bases: this holds true for dia-krinō, which occurs 14 times with a reciprocal meaning in the Homeric poems (it describes non-reciprocal events in four occurrences instead). It mostly (13/14 occurrences) retains its spatial reciprocal basic meaning 'separate one from another', as in (40), and develops into a proper reciprocal dia-kríno only in a single occurrence (41), along the following semantic path: 'separate one from another' $\rightarrow$ 'metaphorically separate in a contest' $\rightarrow$ 'make an agreement'.

\begin{tabular}{|c|c|c|c|c|c|}
\hline (40)tò̀ & diakrinthénte & & hò & mèn & metà \\
\hline 3DU.NOM.M PTC & separate:PTCP.AOR.NOM.I & U.PASS.M & 3SG.NOM & PTC & among \\
\hline laòn & Akhaiôn éeí’, & $h \grave{~}$ & $d^{\prime} \ldots$ & & \\
\hline population:ACC & A.:GEN.PL go:IMPF.3SG & 3SG.NOM & PTC & & \\
\hline
\end{tabular}

'So separating, the one (Aias) went among the Achaian people, and the other (Hektor)...' (Il. 7.306)

(41)iskhesthe

ptolémou,

Ithakếsioi, argaléoio,

hö́s ken

refrain:IMP.PRS.2PL.M/P warfare(M):GEN

I.:VOC.PL grievous:GEN.M so.that PTC

anaimōtí

ge diakrinthête

tákhista

without.bloodshed PTC separate:SBJV.AOR.2PL.PASS the.soonest

'Ithacans, refrain from grievous warfare, so you may separate (make an agreement) the soonest without bloodshed!' (Od. 24.531-2) 


\subsubsection{Constructions of reciprocal preverbs}

The distribution of syntactic constructions also suggests that the emergence of a reciprocal meaning associated with preverbs is highly triggered by the wider sentence context.

As far as reciprocal constructions with preverbs are concerned, in our corpus, we observe a great predominance of the continuous construction (94/103), a much lower frequency of the discontinuous construction (7/103 with five lemmas), exemplified in (42) with the compound ant-histēmi 'stand against', and of the absolute construction (2/103 with two lemmas).

(42) $\underline{H e ̂ ́ r e ̄ i} \quad d ' \quad$ antéstēeladeinè

H.:DAT PTC stand.against:AOR.3SG of.golden.distaff:NOM.M/F lady.of clamor:NOM.F

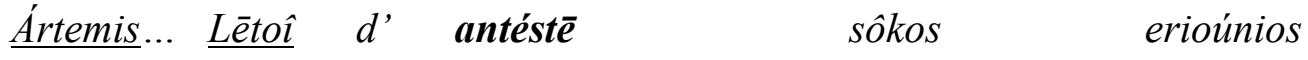

A.(F):NOM L.:DAT PTC stand.against:AOR.3SG strong:NOM.M generous:NOM.M

Hermês, $\quad \underline{\text { ánta }} \quad d^{\prime} \quad$ ár Hēphaístoio...

H.(M):NOM in.front.of PTC PTC H.:GEN

hò̀s hoì mèn theoì ánta theôn

thus DEM.NOM.PL.M PTC god(M):NOM.PL in.front.of god:GEN.PL go:AOR.3PL

'Against Hera stood the lady of clamor, of the golden distaff, (of the showering arrows)

Artemis, (sister of the far striker). Opposite Leto stood the strong one, generous Hermes, and against Hephaistos (stood the great deep-eddying river)... Thus gods went on to encounter gods.' (Il. 20.70-75)

The passage in (42) describes a scene of fighting comprising two reciprocal sub-situations: in the former, Artemis, in subject position, faces Hera, Hếrēi in the dative case (on dative second arguments, cf. Section 3.4.4 with references); in the latter, Hermes faces both Leto, Lètôे in the dative case, and Hephaistos, expressed by a PP with ánta 'in front of' (+GEN). The same PP also occurs in the polyptotic construction theoi ánta theôn 'gods against gods', which closes the fighting scene. Here, 
the unquestionable role of anti- in encoding reciprocity is backed up by the presence of the etymologically related preposition ánta (LIPP 306-311) in the subsequent polyptotic construction (on which cf. the beginning of Section 3 ). In addition, the root $* h_{2} e ́ n t$ - itself constitutes the basis for the formation of a number of lexical reciprocal predicates, that is, ántomai, antáō, antázō, antiáō 'face, meet' (DELG 91-92; LIPP 310).

In (42) above, because of the co-occurrence of a number of derivatives from the inherently reciprocal root $* h_{2} e ́ n t$, , reciprocity is expressed despite the presence of singular subjects, which triggers a non-reciprocal reading in other passages, as the comparison between (43) and (44) shows.

(43)PLURAL SUBJECT $\rightarrow$ RECIPROCAL READING

Trôes kaì Lúkioi kaì Murmidónes kaì Akhaioí

T.:NOM.PL and L.:NOM.PL and M.:NOM.PL and A.:NOM.PL

súmbalon amphì nékui katatethnēôti mákhesthai

throw.together:AOR.3PL on.both.sides body(M):DAT die:PTCP.PRF.DAT.M fight:INF

'Trojans and Lykians, and Myrmidons and Achaians, they clashed together in battle over the perished body.' (Il. 16.565)

(44) SINGULAR SUBJECT $\rightarrow$ NON-RC

tôi dè thúraze erkhoménōi xúmblèto

DEM.DAT PTC through.a.door go:PTCP.PRS.DAT.M/P throw.together:AOR.3SG.PASS

'(Nausicaa is looking for her father.) She ran into him coming through a door.' (Od. 6.53-4)

Both examples attest to the same compound sumbállo (lit.) 'throw together': in (43), its plural subject triggers a reciprocal reading for sun-, which is thus involved in building a weak RC. In (44), instead, the situation described is asymmetric: only Nausicaa is looking for her father, who is simply walking on his own, unaware of his daughter's intentions. Thus, the two participants are construed as playing two different semantic roles as regards their intentionality and agentivity. To conclude, the event of 
meeting someone is of course inherently reciprocal in the real world: if someone meets someone else, the contrary simultaneously happens as well. Nevertheless, the linguistic expression allows for different construals of the same event: thus, an inherently reciprocal event can be construed as a nonreciprocal one by selecting the appropriate construction (cf. Section 3.3.4 with references, on the notion of construal).

\section{Reciprocal constructions in Homeric Greek: a synchronic description}

In Section 3, we have shown how the pronoun allélōn, the middle voice, and preverbs all contribute to encoding the reciprocal domain in HG. In this section, we provide a more structured comparison between the three RCs and single out interesting aspects of their synchronic relationship. In doing so, we elaborate on the distribution of each strategy with regards to the semantic and morphosyntactic parameters introduced in Section 3.1.

To begin with, based on their morphosyntactic properties, the three strategies under analysis represent different types of reciprocal marking. The reciprocal pronoun allếlōn can be classified as a syntactic reciprocal marker. Formally, it resembles a so-called bipartite or two-components quantifier NP strategy, such as English each other (cf. Nedjalkov 2007b: 154-157; Evans 2008: 46). More specifically, it can be described as a reciprocal marker of the polyptotic type, i.e. whose two components are based on the same stem (Fanelli 2009: 66; Kulikov 2014a). However, since its earliest attestation, the pronoun is already highly grammaticalized, as the two components are bound to one another (see further Section 5). The middle voice can be regarded as a morphological marker, as it is formed by a set of verbal endings. Syntactically, the middle operates as a valency reducing strategy, as it turns transitive verbs into intransitives. Finally, preverbs represent a verb-marking strategy to encode reciprocity (on this classification, cf. Evans 2008: 45): they can function as bound or unbounded (cf. example (37)) lexical modifiers of a verbal stem.

The three strategies also differ in their degree of specialization (cf. for a discussion of specialization in relation to grammaticalization, see Hopper 1991: 25-28). The pronoun allélōn is 
fully specialized for the reciprocal function, and it is not polysemous. By contrast, both the middle voice and preverbs are highly polyfunctional. As is well-known, the middle voice is a highly polysemous marker, as it conveys a wide range of intransitivizing functions, besides the lexical uses with the media tantum (see Section 3.3). Similarly, Homeric preverbs, which most likely originated from previous free-standing spatial adverbs (cf. Zanchi forthc.: Section 3.1.3 with references), have not fully univerbated to the modified verb nor have fully grammaticalized yet: they constitute a "problematic morphological category" (Cuzzolin et al. 2006), ranging among the statuses of independent words, clitics, or bound morphemes. Besides modifying a verb, they can also modify the semantics of a whole event (as adverbs) or of a case (as adpositions), as discussed in Section 3.4. The reciprocal meaning is only one among the multiple semantic additions that preverbs can contribute to bringing about. In sum, preverbs are highly polysemous and multi-functional linguistic items: they can carry spatial and other types of lexical meanings, as well as actional (i.e. mostly telic, but also distributive, ingressive, etc.) and other types of more grammatical meanings, including aspectual, applicative-like, and reciprocal function (Section 3.4).

Let us now turn to evaluating how the three strategies differ in terms of the semantic and morphosyntactic parameters discussed in Section 3.1.

The first parameter that we discuss is the distribution of the various strategies with respect to the type of the predicate head. Specifically, we evaluate to what extent each RC under analysis is associated to lexical and grammatical reciprocals on the one hand, and to spatial and proper reciprocals on the other.

Table 9: Homeric RCs and predicate type

\begin{tabular}{|l|l|l|l|}
\hline & Pronoun & Middle & Preverbs \\
\hline
\end{tabular}




\begin{tabular}{|l|l|l|l|l|l|l|}
\hline Type frequency & \multicolumn{4}{l|}{$79^{17}$} & \multicolumn{3}{l|}{80} & \multicolumn{2}{l|}{} \\
& Proper & Spatial & Proper & Spatial & Proper & Spatial \\
\hline Grammatical & 49 & 13 & 1 & 0 & 0 & 0 \\
\hline Lexical & 8 & 9 & 15 & 64 & 5 & 30 \\
\hline
\end{tabular}

As the data in Table 9 neatly shows, a clear-cut difference can be established between the reciprocal pronoun allêlōn on the one hand and the middle voice and preverbs on the other. Indeed, the pronoun is the $\mathrm{RC}$ with the wider distribution already in Homer. As a matter of fact, it shows a strong preference towards grammatical proper reciprocal predicates (49/79), but it also covers, to a lesser extent, spatial and lexical ones. The middle voice and preverbs show a radically different picture. The distribution of the middle as a RC is virtually limited to lexical reciprocals (79/80), i.e. those verbs that inherently express a reciprocal situation (Dimitriadis 2008; verbos simétricos in Revuelta 2010), e.g. mákhomai 'fight' or ántomai 'meet' etymologically connected with ánta and anti 'in front of' (DELG 91-92; LIPP 311). Only with the verb outázō 'stab' does the middle voice operate as a grammatical reciprocal marker. Still, it is striking that the only middle form of this verb with a reciprocal interpretation indicates an event of fighting, much in the same vein as proper lexical reciprocals such as mákhomai 'fight'. In addition, the reciprocal interpretation of the occurrence of outázō discussed under (25)b is backed up by the occurrence of the adverb autoskhedón 'hand to hand'. This can be taken as evidence for a very tenuous relationship between the middle voice and grammatical reciprocals, at least in Homer. Similar considerations hold for preverbs as well, since, as already discussed in Section 3.4.2, preverbs are best analyzed as lexical reciprocals (35/35), in that they either attach to verbs that per se express symmetric event types or make up compounds with

\footnotetext{
${ }^{17}$ The type frequency of the pronoun allélōn in Table 12 differs from the one reported in Table 1 (i.e. 98) because here we only consider those cases in which the pronoun depends from a verbal head (or from a preverb plus verb combination) as shown in Table 2.

${ }^{18}$ Polysemous compound verbs are counted twice. In particular amphi-bállō and dia-krínō can express both spatial and proper reciprocal relationships (cf. examples (38) vs. (39) and (40) vs. (41) in Section 3.4.3).
} 
new, and still lexical, reciprocal meaning. In addition, consistently with preverbs' etymological meanings, preverbs are highly specialized to express spatial reciprocal situations (30/35). It is thus safe to conclude that among the RCs under analysis, the pronoun is the preferred way to express grammatical reciprocals of the proper type.

The second parameter to be discussed is the array of reciprocal situation types that RCs can express. The relevant quantitative corpus data is shown in Table 10.

Table 10: Homeric RCs and situation types

\begin{tabular}{|l|l|l|l|l|}
\hline Situation type & Frequency & & & \\
\hline & Pronoun & Middle & Preverbs & Total \\
\hline Binary & 91 & 5 & 1 & 97 \\
\hline Unary & 18 & 444 & 49 & 511 \\
\hline Strong & 5 & 201 & 13 & 219 \\
\hline Weak & 46 & 16 & 40 & 102 \\
\hline Chaining & 16 & 6 & 0 & 22 \\
\hline Total & $\mathbf{1 7 6}$ & $\mathbf{6 7 2}$ & $\mathbf{1 0 3}$ & 954 \\
\hline
\end{tabular}

As the data in Table 10 shows, the RCs at hand do not distribute evenly across the different situation types. The most striking feature is the stronger association of the reciprocal pronoun with binary (91/176, $52 \%$ vs. middle 5/672, $1 \%)$ and chaining (16/176, $9 \%$ vs. middle 6/672, $1 \%)$ situations, as opposed to the correlation that holds between the middle voice and unary (444/672, 66\%, vs. pronoun $18 / 176,10 \%)$ and strong $(201 / 672,30 \%$, vs. pronoun 5/176, 3\%) situations. Preverbs show an even narrower distribution, as they virtually never occur with binary or chaining situations (note that the one occurrence of the binary situation type in Table 10 is not significant, as the passage $\mathrm{Il} .6 .230$ also contains the reciprocal pronoun and the inherently reciprocal verbal base (ep)-ameíbō 'exchange'; on 
multiple reciprocal marking, cf. below in this section). In addition, preverbs disprefer strong reciprocals $(13 / 103,12 \%)$ : in the few cases where preverbs do encode strong reciprocal situations, the latter must be of a spatial nature.

The existence of a split in the distribution of the pronoun as opposed to the middle voice and preverbs also clearly comes up if one considers how these strategies distribute with respect to temporal unfolding, as shown in Table 11.

Table 11: Homeric RCs and temporal unfolding

\begin{tabular}{|l|l|l|l|l|}
\hline Temporal relationship & \multicolumn{4}{l|}{ Token frequency } \\
& Pronoun & Middle & Preverbs & Total \\
\hline Sequential & 82 & 10 & 9 & 101 \\
\hline Simultaneous & 94 & 662 & 94 & 850 \\
\hline & $\mathbf{1 7 6}$ & $\mathbf{6 7 2}$ & $\mathbf{1 0 3}$ & 954 \\
\hline
\end{tabular}

From the data in Table 11, a strong polarization emerges, whereby the pronoun can express both sequential $(82 / 176,47 \%)$ and simultaneous $(94 / 176,53 \%)$ situations, whereas middle verbs and preverbs are virtually restricted to the expression of simultaneous situations $(662 / 672,99 \%$ and 94/103, 95\% respectively). It follows that, since the middle and preverbs are almost confined to simultaneous situations, it is the pronoun that turns out to be strongly preferred for the expression of sequential events.

To sum up, the reciprocal pronoun can express all kinds of reciprocal situations in terms of reciprocal situation types and temporal relationships. As compared to the other RCs, the pronoun shows a preference for binary and sequential situations. This preference is not entirely random, as it is likely to reflect an older state of affairs whereby the pronoun, by virtue of its etymology (cf. Section 5), was restricted to the encoding of binary situations involving two participants only, and only later 
extended to expressing other situation types. By contrast, both the middle voice and preverbs show a strong preference for unary/strong and simultaneous events, i.e. single-event situations (Maslova 2008: 243), i.e. those situations that feature a low degree of participants' and sub-events' distinguishability (Kemmer 1993: 109-123). This semantic specialization is not entirely surprising, since it has been observed that in languages that have more than one reciprocal marker, less complex strategies, including morphological ones such as the AG middle voice and preverbs, are more likely to conceptualize single-events situations (cf. Maslova 2008: 229).

Finally, let us consider the syntax of the three RCs under analysis in terms of their diathesis. Again, the data in Table12, points at a split in the distribution of allélōn as opposed to the middle voice and preverbs.

Table 12: Homeric RCs and diathesis

\begin{tabular}{|c|c|c|c|c|c|}
\hline & Configuration & $\begin{array}{l}\text { Subject oriented } \\
\text { (direct/indirect) }\end{array}$ & $\begin{array}{l}\text { Object } \\
\text { oriented }\end{array}$ & Possessive & Adverbial \\
\hline \multirow[t]{3}{*}{ Frequency } & Pronoun & 92 & 2 & $14^{19}$ & 68 \\
\hline & Middle & 609 & 63 & - & - \\
\hline & Preverbs & 66 & 37 & - & - \\
\hline
\end{tabular}

As is cross-linguistically valid for most reciprocal pronouns, allélōn can be regarded as a binary marker, in that it syntactically fills in the valency frame of the verb and thus leaves the valency of the base verb unaltered (Maslova 2008: 230). As expected from syntactic pronominal RCs, the pronoun

\footnotetext{
19 The mismatch between the amount of possessive reciprocals (Table 12, 14 tokens) and the overall frequency of the genitive forms of the pronoun (Section 3.2.3, Table 3, 32 tokens) is due to the fact that besides being the case of the possessor, in AG, and especially in Homer, the genitive can also express second arguments with a number of verbs (see Section 3.2.4).
} 
covers all possible diathesis configurations and complies with Nedjalkov's hierarchy of distribution of RCs across different syntactic roles (2007a: 69):

$$
\text { canonical }(\text { direct })>\text { indirect }>\text { possessive }>\text { adverbial }
$$

The preverbs and the middle are instead restricted to subject- and object-oriented reciprocals only. Leaving a few deponent transitive object-oriented media tantum and the marginal use of lability aside, middle verbs with reciprocal meaning, both media tantum and oppositional verbs, are syntactically intransitive and subject-oriented (67 intransitives vs. 13 transitives, cf. Section 3.3.). Specifically, the middle voice prevalently acts as an intransitivizing marker with object-oriented spatial reciprocals, with either anticausative or passive functions. These verbs occur in different constructions, i.e. simple, discontinuous, and absolute, depending on the construal of the participants' contribution to the reciprocal event. Concerning preverbs, depending on the transitivity and voice of the verb bases onto which they attach, they can contribute to encoding either subject- or objectoriented reciprocal situations, without anything significant to observe about preverbs per se in this respect. Apart from a very few exceptions (cf. Section 3.4.4), reciprocal constructions with preverbs are limited to the simple constructional type.

From the above discussion, one can conclude that the three RCs largely stand in a complementary distribution, as they cover different syntactic and semantic domains. This distribution is not random: instead, it results from the very nature of these constructions and also reflects their historical sources (see further Section 5). Specifically, the middle voice and the preverbs tend to show a narrower distribution as compared to the pronoun, as shown in Table 13.

Table 13: parameters of distribution of RCs in Homer 
subject-/object-oriented

lexical reciprocals

spatial reciprocal, single-event situations subject- (dir./indir.), object-, adverbial, possessive

grammatical and lexical reciprocals

proper and spatial reciprocals, all situation types

Cases of overlap between the three constructions are rare, but nevertheless attested. For example, the reciprocal pronoun marginally co-occurs with lexical spatial middle verbs, e.g. mígnumi 'mix' in (45); instead, in our corpus, it appears that verbs that freely alternate between the active and the middle voice occur with the pronoun only in the active, as happens with erizo 'contend' in (46):

(45)epeì thamà tô̂on emisgómeth' allếloisin

since often so mix:IMPF.3PL.M/P RECP.DAT.PL

'Since we every so often got together with each other.' (Od. 1.209)

(46) ho xeînós te kaì Îros

erízeton

allếloïn

DEM.NOM stranger:NOM PTC and I.:NOM provoke:PRS.3DU

RECP.DAT.DU

'Irus and the stranger are provoking each other.' $(\mathrm{Od} .18 .38)$

Preverbs attach onto middle verbs that are inherently reciprocal in 28 occurrences (tokens), e.g. ageírō vs. sun-ageirō 'gather', and the reciprocal pronoun occurs only with a couple of reciprocal verbs modified by a preverb, specifically amphi-bállō and ep-ameíbō. The pronoun crucially contributes to expressing the proper reciprocal meaning 'embrace', as shown by comparing (38) and (39) (Section 3.4.3). All in all, it appears that the pronoun can be optionally added to disambiguate the polysemy of middle voice and preverbs, backing up the reciprocal semantics of lexical reciprocal verbs marked with either of these strategies (cf. Revuelta 2017 on Latin inter se).

In Homer, there is one single passage in which the three strategies co-occur, shown in (47), where the verb inflects in the middle voice, is modified by the preverb sun- and takes the pronoun allêloisi. Since the verb (sun)-ántomai is etymologically connected with ánta and antì 'in front of' (cf. above 
in this section), one could even consider example (47) as attesting to a case of quadruple reciprocal marking.

$\begin{array}{llllll}\text { (47)alléloisi } & \text { dè } & \text { tố } & \text { ge sun-antésthēn } & \text { parà } \\ \text { RECP.DAT.PL } & \text { PTC } & \text { DEM.NOM.DU } & \text { PTC } & \text { together-meet:IMPF.DU.M/P beside } \\ \text { phēgôi } & & & & \\ \text { oak.tree:DAT } & & & \end{array}$

'These two then encountered each other beside the oak tree.' (Il. 7.22)

Judging from the evidence gathered in this section, it seems that already in Homer, the pronoun allêlōn represents the most widespread and conventionalized means to encode reciprocity. Its wider distribution can be better captured in terms of higher syntactic productivity, here understood as in Barðdal (2008). ${ }^{20}$ According to Barðdal (2008), productivity can be further decomposed into three parameters, that is, generality, regularity, and extensibility. Generality broadly refers to a construction being the default strategy to encode a certain domain and correlates with wider coverage and higher schematicity. The pronoun allélōn displays a higher generality as compared to the middle voice and preverbs. Not only can the pronoun express the whole syntactic and semantic range of RCs in terms of diathesis configurations and situation types, but it also displays the highest rate of type/token frequency, i.e. $98 / 176(0,6)$ (preverbs 33/103 $(0,3)$; middle voice $80 / 672(0,1)$ ). This means that the pronoun combines with the highest rate of different lemmas. The pronoun also scores high on regularity, since it is a specialized marker, its use is fully transparent, and it has a fully predictable compositional meaning. In this respect, the use of the pronoun can be described as instantiating a

\footnotetext{
${ }^{20}$ Linguistic productivity is notoriously a difficult parameter to assess. Apart from Barðdal's (2008) model, we are well aware that different approaches to productivity exist (see e.g. Hilpert 2013: 127-133 with references). Nevertheless, we think that Barðdal's (2008) model is particularly suited to offer a well-measurable and quantifiable productivity of syntactic constructions.
} 
rule-based grammatical pattern. This contrasts with the both the middle voice and preverbs, which are both highly polysemous and less transparently linked with reciprocity. This is especially true for preverbs. In fact, in Homer, for reciprocity to emerge and be associated with preverbs, other contextual clues than preverbs frequently have to co-occur: verbal semantics of a spatial type, a plural subject (in simple RCs), or other unambiguous markers of reciprocity, including the reciprocal pronoun and/or an adverb/preposition with reciprocal meaning. At the moment, we lack data to ascertain the extensibility of the pronoun allélōn, that is, its ability to combine with new verbs over time. For this purpose, diachronic corpus-data on post-HG is at need, and we leave the issue for future study (however, we do know that allélōn developed into a bound prefix in Modern Greek [cf. fn. 21], which also suggests much regarding its frequency and thus its productivity).

\section{The diachrony of RCs in Ancient Greek: preliminary remarks}

As is well-known, RCs historically derive from a restricted pool of conceptual sources and develop through selected paths of language change (Heine \& Miyashita 2008: 177; Kulikov 2014a). A thorough historical exploration of RCs in AG lies beyond the scope of this paper. In this section, we only provide a few preliminary observations on how diachrony can contribute to shedding light on two aspects concerning the synchronic behavior of Homeric RCs discussed in Section 3 and in Section 4. On the one hand, we argue that the observed distribution of Homeric RCs partly reflects each construction's origin. On the other hand, we single out aspects of this distribution that might offer clues as to the perspective development of RCs in later stages of Greek.

The origin of the reciprocal pronoun allêlōn is quite straightforward. According to most authors, allélōn goes back to the iteration of the root *ali- 'other' (or *h $h_{2}$ el-io- cf. DELG 63; Beekes 2010: 72). Originally, it is likely that the pre-form of allélōn consisted in a polyptotic construction with the root *ali- iterated and inflecting in different case forms. Evidence for such a polyptotic construction comes from e.g. Latin ali- ali- and Sanskrit anyo-(a)nya-, which show a lesser degree of morphological integration as compared to AG allélōn (Krisch 1999; Kulikov 2014a: 150; LIPP 21- 
27). In this respect, the AG pronoun allêlōn instantiates both the ONE-ANOTHER and the REPETITION schemas (Heine \& Miyashita 2008). However, unlike the Latin ali- ali- construction, Greek allếlōn has proceeded further along the univerbation cline: (i) its two components are fully univerbated since its earliest occurrences, (ii) its first component does not show inflectional features, and (iii) the form cannot be interrupted by other linguistic material, e.g. ep 'alléloisi vs. Italian l'uno sull'altro. Despite these similarities, note that one should be cautious in projecting the pronoun *ali-ali-as a full-fledged reciprocal marker back to PIE. All in all, even though *ali- could have already occurred in iterated constructions with a reciprocal-like semantics in the proto-language, if one takes into account the different degrees of grammaticalization of the *ali-ali- construction in individual IE languages at different chronological heights, it is likely that the development of a full-fledged reciprocal pronoun was independently achieved in the daughter languages.

The emergence of reciprocal pronouns out of bipartite constructions such as English each other Italian l'un l'altro, German einander, and Greek allélōn has prompted a lively debate on the nature of this type of language change. Scholars have pointed out that processes giving rise to such pronouns share features of both grammaticalization, i.e. the development of a new grammatical meaning, and lexicalization processes, i.e. the creation of a new univerbated lexeme (see Haas 2007 with references). Given that allêlōn is univerbated since its earliest attestations, Greek does not offer firsthand data to track down how the pronoun emerged in the first place. However, given the typological similarity with the history of English each other, we prefer to avoid speaking of the grammaticalization vs. lexicalization binary distinction, and follow Haas (2007: 37-43) in describing the type of process that might have led from PIE *ali- *ali- 'the one...the other' to Greek allélōn 'each other' in terms of grammatical constructionalization.

A final note is in order on the origin of Greek allélōn. In discussing possible functional motivations for the creation of reciprocal pronouns, it has been observed that syntactic reciprocal pronouns may originate in contexts in which speakers first exploit them to disambiguate a reciprocal reading of a highly polysemous intransitivizing marker (e.g. Vezzosi 2010). Only later has the newly created 
pronoun become conventionalized as a specialized RC. A good case in point is Italian, in which the reciprocal pronoun l'un l'altro originally arose in contexts in which it served to single out a reciprocal reading of polysemous reflexive si, to the effect that the two must still co-occur in Modern Italian (cf. Vezzosi 2010). This is however hardly the case of Greek, where the pronoun is the only marker of grammatical reciprocals, and only marginally co-occurs with other means of encoding reciprocity, e.g. the middle voice or preverbs. In other words, Greek allélōn possibly did not undergo a stage in which it systematically served as a disambiguating marker, but rather was created specifically for the purpose of encoding reciprocity, which was a domain that lacked a dedicated encoding strategy. As reported in most reference grammars of $\mathrm{AG}$, the pronoun remains the standard means to encode reciprocity throughout Classical Greek. Still, further study is needed to fully understand whether its distribution with respect to the parameters discussed in Section 3.1 and 3.2 changes over time. ${ }^{21}$

Diachronically, the association of the middle voice with reciprocity is undoubtedly more intricate to disentangle, given the extremely complex prehistory of the grammatical category of middle in AG. In principle, as the Greek middle is associated with reflexivity, one could speculate that the reciprocal function of the middle voice derives from the reflexive use with plural subjects, which constitutes a common bridging context in the REFLEXIVE > RECIPROCAL drift (Kemmer 1993; König \& Siemund 2000; Heine \& Miyashita 2008). However, a reflexive origin for the reciprocal function of the middle is unlikely for at least two reasons. In the first place, in Homer, the reflexive function of the middle is still underdeveloped, and reflexivity is most often encoded by a dedicated reflexive pronoun (Puddu 2005: 171; Romagno 2010: 431). In the second place, reciprocals that derive from reflexives are generally grammatical reciprocals; however, as discussed in Section 3.3 and in Section 4, in Homer the middle voice is more robustly associated with lexical reciprocals.

\footnotetext{
${ }^{21}$ The pronoun allêlōn survived up to Modern Greek, but with a notable change: it evolved from a free-standing pronoun into a bound verbal prefix allilo- (cf. Mackridge 1985: 89; Asproudi 2005). Notably, Modern Greek also developed a new analytic reciprocal pronoun o enas to allo 'one another' (cf. Mackridge 1985: 89; Asproudi 2005).
} 
Concerning the lexical reciprocal media tantum, a possible scenario is that these verbs' voice inflection is simply inherited from PIE. However, investigating the PIE background of the middle is not of much help either. Media tantum with reciprocal semantics show up in several IE languages (Krisch 1999), e.g. in Latin (Fanelli 2009), Vedic (Kulikov 2007), and Hittite (Inglese 2017). Nevertheless, as remarked in Section 3.3.1, the distribution of lexical reciprocal media tantum varies across languages and only the root * $s e k^{u}$ - 'be associated/united with' (cf. $L I V^{2} 525$ for comparanda) can be securely reconstructed for PIE. This is to say that the class of reciprocal media tantum in HG cannot be entirely inherited from PIE but must also feature genuine inner-Greek formations. This is especially clear for denominal verbs such as dēriáomai, which is an inner-Greek formation based on the noun dêris 'battle' (DELG 275; Beekes 2010: 326)..$^{22}$

An alternative scenario that can better account for the distribution of verbal voice with reciprocal situations regards the anticausative function of the middle voice as primary, similarly to what suggested by Inglese $(2017,2018)$ for Hittite. There is indeed evidence that in HG oppositional usages of the middle voice were largely underdeveloped, and that the existing oppositional verbs were mostly anticausatives (cf. Romango 2010; Sausa 2016; see also Luraghi forthc. for discussion). In its anticausative function, the middle voice could also be used to derive anticausatives from transitive lexical reciprocal verbs of the spatial type, as discussed in Section 3.3.3. Through these contexts, in which the anticausative middle voice combines with inherently reciprocal verbs, speakers could have

\footnotetext{
${ }^{22}$ Interestingly, individual verbs that synchronically fall within the media tantum class in Homer may not necessarily have been inherited as such from PIE. An instructive case in point is márnamai 'fight'. In Greek, this verb is a lexical reciprocal that belongs to the media tantum group. However, the verb is etymologically connected with Sanskrit mrnáti 'crush', which is consistently active and displays transitive syntax (see DELG 668; Beekes 2010: 905; LIV 440). The comparison between AG márnamai 'fight' and Sanskrit mrnáti 'crush' suggests that in the protolanguage the verb might have been able to occur both in the active and in the middle voice to indicate a reciprocal alternation of the grammatical type 'crush, hit:ACT' vs. 'hit each other $\rightarrow$ fight:MID', and that AG preserved only the latter formation in the lexicalized meaning 'fight' (on the lexicalization 'hit each other' $\rightarrow$ 'fight', see Alpatov \& Nejalkov 2007: 1059; internally to AG, similar considerations hold for the medium tantum plēktizomai 'fight', which is etymologically connected with plêssō 'hit'; cf. DELG 917; LIV 484).
} 
inferred a relationship between the middle voice and reciprocal semantics. Then, speakers could have analogically extended middle marking to other reciprocal situations, including e.g. proper verbs of fighting and contending, thus paving the way for the middle's use as a grammatical reciprocal marker with verbs such as outázō 'stab'. Such an account, however tentative, has the merit that it explains why the middle shows such strong association with anticausative spatial lexical reciprocals. It is interesting to observe that the middle voice is employed as a marker of grammatical reciprocals even in later stages of AG, even though to a seemingly limited extent. An often-cited piece of evidence (cf. Allan 2003) is the passage from Herodotus reported in (48): here, the same reciprocal event 'kiss each other' is consecutively indicated through a construction with the active verb philéousi and the reciprocal pronoun allêlous and through the middle verb philéontai.

\begin{tabular}{|c|c|c|c|c|c|}
\hline (48)antì $\quad g$ & $\grave{a} r$ tôे & prosagoreúein & allếlous & philéousi & toîsi \\
\hline instead fo & ART.GEN & greet:INF.PRS & RECP.ACC.PL & kiss:PRS.3PL & DEM.DAT.PL.N \\
\hline stómasi. & $\grave{e n}$ & $d \grave{e} \quad \hat{e} i$ & hoúteros & upodeésteros & \\
\hline $\operatorname{mouth}(\mathrm{N})$ : & DAT.PL & PTC be:SBJV.3SG & either:NOM.M & humble:COMP & NOM.M \\
\hline olígōi, & tàs & pareiàs & filéontai & & \\
\hline little:DAT & ART.DEM.F & cheek(F):ACC.PL & kiss:PRS.3PL.M/ & & \\
\hline
\end{tabular}

The emergence of reciprocal meanings seems to be associated with a small subset of preverbs in a number of ancient IE languages, which attest to comparable developments: (i) PIE $* h_{2} e m b^{h} i$ 'on both sides' (LIPP 35-40), cf. AG amphi- and Old Irish imm ( $\left.a^{-}{ }^{N}\right)$; (ii) *dvis 'in two (directions)' (LIPP 145-147), cf. AG dia-, Vedic ví, and Latin dis-; (iii) various preverbs meaning 'together', disputably going back to the same etymological source, including AG sun-, Sanskrit sám, and Latin com- (DELG 767; LIPP 717-729; Neri 2013 with references). Thus, either etymologically connected or 
semantically similar preverbs develop reciprocal meanings in different languages. What do these preverbs have in common? They all share some kind of (dis)sociative meanings related to the notions of spatial and non-spatial unity or dyad. Again, to account for the development into reciprocals, the well-known polysemy between comitative, sociative, and reciprocal comes into play (cf. Section 3.4.1 with references; see also Dedio \& Widmer 2017: 8 for discussion on this polysemy as associated with the Old Irish reciprocal marker $\operatorname{imm}\left(a^{-}{ }^{N}\right)-$. As for the remaining Homeric reciprocal preverbs, anti- 'in front of' can be regarded as a lexical reciprocal lexical item: as Bortone (2010: 183) puts it, "the original distinction between them [i.e. antí and pró] was that antí indicated that one object was facing the other". This is not true in all ancient IE languages: for example, Latin ante- simply means 'before', and not necessarily 'in front', and accordingly it does not function as a reciprocal marker (but cf. Hittite menahhanda 'in front of', Inglese 2017: 997). In Section 3.4.1, we have already explained how the reciprocal meaning of meta- arguably arose from its 'after' meaning. The same semantic development accounts for the reciprocal meaning of epi- 'on': this uninflected morpheme has a rather complex semantics (Luraghi 2003b: 298-313); however, when it functions as a preverb, one of its most common meanings is that of 'in addition' (directly derived from its 'on' meaning) $\rightarrow$ 'after'.

It is not straightforward to assign RCs with preverbs back to PIE for a number of reasons. First, throughout their history, different IE languages elected different preverbs as the most productive ones to encode reciprocity: for example, in Vedic vi' 'in two parts' is the most common reciprocal preverb (Kulikov 2007), whereas sun- 'with' enjoys the highest frequency in Homer, despite remaining less paradigmaticized than Vedic ví. In addition, as far as we know, comparable preverb+verb reciprocal collocations can only be reconstructed to a very limited extent for PIE: see PIE $* d i s s \hat{k}^{h} i d->$ Vedic $v i$ chid- 'divide', AG dia-skhizō 'slash, tear', and Latin dis-cindere 'split' (however, in AG, this compound shows no truly reciprocal semantics in Homer, cf. Od. 9.71); PIE *dis steh $2^{-}>$AG diistèmi 'stand apart, Gothic twisstandan 'stand apart', and possibly Latin distāre 'be separated' (LIPP 146-147); PIE *su(m) $b^{h}$ er- > post-HG sum-phérō 'bring together, collect' and Old Church Slavic 
sǔbürati 'collect'; PIE *sóm $d^{h} e_{1^{-}}>$Vedic sam dhā- 'put together' and post-Homeric sun-títhēmi 'put together'. Despite these few cognate sets, this point undoubtedly requires further investigation: given that the semantic developments that turned this sub-set of IE preverbs into reciprocal markers are typologically plausible, the listed collocations could also be a matter of subsequent, parallel, and independent developments, rather than of genealogical inheritance. Moreover, preverbs of the earliest branches of IE were only at the onset of their grammaticalization processes, and thus likely not yet associated with grammatical functions, including encoding reciprocity, in PIE (Cuzzolin et al. 2006; Luraghi 2010; Zanchi forthc.).

The above-mentioned hypothesis that a link holds between the concept of dyad and reciprocity is backed up by the history of amphi- in AG: already in post-HG, the meaning of amphi-broadened from 'on both sides' into 'on all sides, around' (Chantraine 1953: 129-130; Luraghi 2003b: 256; Zanchi forthc.: Section 5.4), and consequently its connection with the notion of dyad became less clear; accordingly, amphi- lost its reciprocal function in post-HG. In spite of the loss of amphi-, in post-HG, additional preverbs developed the ability to make up compounds used in reciprocal contexts (cf. e.g. pros- 'toward' in pros-gígnomai 'attach oneself to another'). Furthermore, new composites with Homeric reciprocal preverbs started being attested in post-HG: for example, anti- counts four lemmas in Homer, but 62 lemmas in post-HG; dia HG x7 vs. post-HG x58; sun- HG x19 vs. postHG x190 (lemmas manually extracted from $L S J$ ). Thus, the reciprocal meaning became increasingly associated with certain preverbs, which eventually developed into full-fledged markers of grammatical reciprocals, as shown by compounds such as ant-adikéo 'repay offence with offence', dia-dáknō 'bite each other', and sum-filéō 'love mutually'. At a first sight, it is also interesting that different preverbs seem to occupy different portions of the reciprocal conceptual domain, in a way that their distribution is consistent with their etymology: for example, anti- 'in front of' (DELG 9192, LIPP 306-311) specialized for sequential or delayed reciprocals (response reciprocal[s] in Nedjalkov 2007a: 94), as in anti-miséo '(lit.) hate in front' $\rightarrow$ 'hate in return' $\rightarrow$ 'pay smbd. with hate for hate'. 


\section{Conclusions}

In this paper, we systematically analyzed how different strategies contribute to the expression of reciprocity in HG. Grounding our investigation on quantitative corpus data taken from the $A G L D T$ 2.0, HoDeL 2.0 (Zanchi et al. 2018), and The Chicago Homer, we focused on the three main RCs out of those described in reference grammars (cf. Section 3): the reciprocal pronoun allélōn, the middle voice, and preverbs.

At first, we observed the synchronic distribution of these RCs (Sections 3.2-3.4), taking into account various semantic and morphosyntactic parameters relevant for each of them, as suggested by

previous typological studies on reciprocity: (i) the predicate type (spatial vs. proper reciprocal; inherent vs. non-inherent reciprocal); (ii) the situation type (binary, unary, strong, weak, chaining reciprocals); (iii) the sub-events temporal relationship (sequential vs. simultaneous); (iv) the reciprocal marker type (syntactic, morphological, lexical); (v) the diathesis of the RC (subjectoriented direct, subject-oriented indirect, object-oriented, possessive, adverbial); (vi) the RC type (simple, discontinuous, absolute).

As Section 4 thorough shows, it turned out that the reciprocal pronoun, the middle voice, and preverbs partly cover complementary conceptual and morphosyntactic sub-domains of reciprocity. In particular, the reciprocal pronoun allélōn enjoys the widest distribution: it is entitled to encode spatial and proper reciprocals and all situation types, with a preference for binary and sequential even types. It functions as a grammatical reciprocal marker of the syntactic type, and as such is able to occur in all possible diathetical and constructional configurations. By contrast, middle's and preverbs' distributions are far narrower: they are both virtually limited to spatial and lexical reciprocals of the single-event type, and to subject- and object-oriented configurations. In addition, these strategies show a null (preverbs) or an extremely limited (middle voice) ability to function as grammatical markers of reciprocity. Thus, the reciprocal reading of the middle voice and preverbs is crucially context-driven, most likely due to the high degree of polysemy of these markers. 
The outlined rather different distributions are claimed to be at least in part diachronically motivated (Section 5). The reciprocal pronoun can be easily traced back to a polyptotic construction. The latter instantiates the so-called REPETITION schema (Heine \& Miyashita 2008: 182), which crosslinguistically constitutes a common source to encode reciprocity, most likely owing to its iconicity (Nedjalkov 2007b: 154). Instead, the historical motivations behind the middle voice and preverbs being used as reciprocal markers is far more complex. Arguably, these two developments have in common the fact that, for both of them, the reciprocal reading emerged in specific bridging contexts, later on conventionalized, and finally analogically extended to unmotivated contexts. Anticausative middles of inherently reciprocal verbs are likely to have constituted the starting points for the association between middle voice and reciprocity. Similarly, specific preverbs, and especially those indicating a spatial or non-spatial unity or dyad, could initially have reinforced the inherently reciprocal semantics of a simplex verb or have formed new spatial reciprocal compounds in front of location or motion verbs.

Section 5 also touched upon the intricate issue of reconstructing a reciprocal pronoun of the type *ali-ali- and a reciprocal usage of the middle voice and of preverbs for PIE, pointing out, for each strategy, the difficulties behind this task. Finally, without aiming at exhaustiveness, we offered a few insights on how these reciprocal markers evolved in post-HG, which is a topic we would like to investigate systematically in a future study.

All in all, from a broader and methodological standpoint, we believe that this paper contributes to showing, once again, how typological approaches can be fruitfully applied to ancient languages: the analytical tools developed within linguistic typology can help shed light on how seemingly competing constructions in fact occupy quite distinct portions of a certain conceptual domain. Conversely, we also hope to have shown how profitable it can be to counterpart such a typological approach with a philological attention to linguistic data and a diachronically-oriented search for explanations: the former wards off the risk of oversimplifications, the latter may find motivations to apparent idiosyncrasies. 


\section{References}

AGLDT $2.0=$ Ancient Greek and Latin Dependency Treebank 2.0:

https://perseusdl.github.io/treebank_data/.

Allan, Rutger J. 2003. Middle voice in Ancient Greek. A Study of Polysemy. Leiden: Brill.

Asproudi, Evangelia. 2005. Reflexive and Reciprocal Constructions in Modern Greek. The ITB Journal 6(2). Article 2. https://arrow.dit.ie/itbj/vol6/iss2/2 (accessed 25 January 2019).

Bar-Asher Siegal, Elitzur A. 2014. NP-strategies in Semitic languages in a typological perspective. Diachronica 31(3). 337-378.

Barðdal, Johanna. 2008. Productivity. Evidence from Case and Argument Structure in Icelandic. Amsterdam \& Philadelphia: John Benjamins.

Beekes, Robert. 2010. Etymological dictionary of Greek. Leiden: Brill.

Bertrand, Nicolas. 2014. On tmesis, word order and noun incorporation in Homeric Greek. In Annamaria Bartolotta (ed.), The Greek verb. Morphology, Syntax, and Semantics. Proceedings of the 8th International Meeting on Greek Linguistics (Agrigento, October 1-3, 2009), 11 - 30. Louvain: Peeters.

Bortone, Pietro. 2010. Greek prepositions: from antiquity to present. Oxford: OUP.

Bozzone, Chiara. 2014. Constructions: A New Approach to Formularity, Discourse, and Syntax in Homer. Los Angeles, CA: University of California Los Angeles dissertation.

Chantraine, Pierre. 1953. Grammaire homérique. Tome 2: Syntaxe. Paris: Klincksieck.

Conti, Luz. 2006. Untersuchung der sogenannten inhärent reziproken Verben im Altgriechischen: Semantische und syntaktische Eigenschaften. Historische Sprachforschung/Historical Linguistics 119. 168-185.

Creissels, Denis. 2006. Syntaxe générale, une introduction typologique. Paris: Hermès.

Crespo, Emilio, Luz Conti \& Helena Maquiera. 2003. Sintaxis del Griego Clásico. Madrid: Editorial Gredos. 
Croft, William \& Alan D. Cruse. 2004. Cognitive Linguistics. Cambridge: CUP.

Cuzzolin, Pierluigi. 2015. Reciprocals in Latin. A reappraisal. In Gerd V. M. Haverling (ed.), Latin Linguistics in the Early $21^{\text {st }}$ Century: Acts of the 16th International Colloquium on Latin Linguistics (Uppsala, June 6th-11th, 2011), 221-239. Uppsala: Acta Universitatis Upsaliensis. Cuzzolin, Perluigi, Ignazio Putzu \& Paolo Ramat. 2006. The Indo-European Adverb in diachronic and typological perspective. Indogermanische Forschungen 111. 1-38.

Danesi, Serena. 2009. Uso e significato della preverbazione in vedico: la testimonianza del Rgveda. Pisa: Università degli Studi di Pavia dissertation.

Darlymple, Mary, Makoto Kanazawa, Yookyung Kim, Sam Mchombo \& Stanley Peters. 1998. Reciprocal expressions and the concept of reciprocity. Linguistics and Philosophy 21. 159-210.

De Angelis, Alessandro. 2004. Forme di "tmesi" nel greco omerico, la legge di Wackernagel e un caso di rianalisi sintattica. In Giovanna Rocca (ed), Dialetti dialettalismi, generi letterari e funzioni sociali. Atti del V Colloquio Internazionale di Linguistica Greca (Milano, 12-13 settembre 2002), 179 - 214. Alessandria: Edizioni dell’Orso.

De Decker, Filip. 2015. A Morphosyntactic Analysis of Speech Introductions and Conclusions in Homer. München: Ludwig Maximiliansuniversität dissertation.

Dedio, Stefan \& Paul Widmer. 2017. S, A, and P argument demotion with preverbal imm- $\left(a-^{N}\right)-$ in Old and Middle Irish. Études Celtiques 43. 187-206.

DELG = Chantraine, Pierre. 1968. Dictionnaire étymologique de la langue grecque. Histoire des mots. Paris: Klincksieck.

Dimitriadis, Alexis. 2008. Irreducible symmetry in reciprocal constructions. In Ekkehard König \& Volker Gast (eds.), Reciprocals and reflexives: Theoretical and cross-linguistic explorations, 375-410. Berlin \& New York: Mouton de Gruyter.

Georgakopoulos, Thanasis. 2018. A frame-based approach to the source-goal asymmetry. Synchronic and diachronic evidence from Ancient Greek. Constructions and Frames 10(1). 61-97. 
Evans, Nicholas. 2008. Reciprocal constructions: Towards a structural typology. In Ekkehard König \& Volker Gast (eds.), Reciprocals and reflexives: Theoretical and cross-linguistic explorations, 33-103. Berlin \& New York: Mouton de Gruyter.

Evans, Nicholas, Stephen C. Levinson, Alice Gaby \& Asifa Majid. 2011. Introduction: Reciprocals and semantic typology. In Nicholas Evans, Stephen C. Levinson, Alice Gaby \& Asifa Majid (eds.), Reciprocals and semantic typology, 1-28. Amsterdam \& Philadelphia: John Benjamins. Fanelli, Valentina. 2009. Le costruzioni reciproche nella lingua latina. Roma: Universitaria editrice. Frajzyngier, Zygmunt \& Traci S. Curl (eds.). 2000. Reciprocals: Forms and functions. Amsterdam \& Philadelphia: John Benjamins.

Haas, Florian. 2007. The development of English each other: grammaticalization, lexicalization, or both?. English Language and Linguistics 11(1). 31-50.

Hajnal, Ivo. 2004. Die Tmesis bei Homer und auf den mykenischen Linear B Tafeln- ein chronologisches Paradox?. In J.H.W. Penney (ed.), Indo-European perspectives: Studies in honour of Anna Morpurgo Davies, 146-177. Oxford: OUP.

Haspelmath, Martin. 1987. Transitivity alternations of the anticausative type [Arbeitspapiere, N. F. 5]. Cologne: Institut für Sprachwissenschaft.

Haspelmath, Martin. 2007. Further remarks on reciprocal constructions. In Vladimir P. Nedjalkov, Emma Š. Geniušene \& Zlatka Guentchéva (eds.), Reciprocal constructions, 2087-2115. Amsterdam \& Philadelphia: John Benjamins.

Haspelmath, Martin. 2016. Universals of causative and anticausative verb formation and the spontaneity scale. Lingua Posnaniensis 58(2). 33-63.

Haug, Dag T.T. 2011. Tmesis in the epic tradition. In Øivind Andersen \& Dag T.T. Haug (eds.), Relative chronology in early Greek epic poetry, 96-105. Cambridge: CUP.

Haug, Dag T.T. 2012. Syntactic conditions on null arguments in the Indo-European Bible translations. Acta Linguistica Hafniensia 44(2). 129-141. 
Heine, Bernd \& Hiroyuki Miyashita. 2008. The intersection between reflexives and reciprocals: A grammaticalization perspective. In Ekkehard König \& Volker Gast (eds.), Reciprocals and reflexives: Theoretical and cross-linguistic explorations, 169-224. Berlin \& New York: Mouton de Gruyter.

Hilpert, Martin. 2013. Constructional Change in English. Developments in Allomorphy, Word Formation, and Syntax [Studies in English Language]. Cambridge: CUP.

HoDeL = The Homeric Dependency Lexicon: https://alessiopalmero.unipv.it/hodel/.

Hopper, Paul. 1991. On some principles of grammaticalization. In Elizabeth C. Traugott \& Bernd Heine (eds.), Approaches to grammaticalization, 17-35. Amsterdam \& Philadelphia: John Benjamins.

Hopper, Paul J. \& Sandra A. Thompson. 1980. Transitivity in Grammar and Discourse. Language 56. 251-99.

Horrocks, Geoffrey C. 1981. Space and Time in Homer: Prepositional and Adverbial Particles in the Greek Epic. New York: Arno Press.

Horrocks, Geoffrey C. 2010. Greek. A History of the Language and its Speakers. Oxford: Blackwell. Inglese, Guglielmo. 2017. A synchronic and diachronic typology of Hittite reciprocal constructions. Studies in Language 41(4). 956-1006.

Inglese, Guglielmo. 2018. The Hittite middle voice. Pavia: Università degli Studi di Pavia dissertation. Karantzola, Eleni \& Nikolaos Lavidas. 2014. On the relation between labilizations and neuter gender: Evidence from the Greek diachrony. Linguistics 52. 1025-1059.

Kemmer, Suzanne. 1993. The Middle Voice. Amsterdam \& Philadelphia: John Benjamins.

Keydana, Götz \& Silvia Luraghi. 2012. Definite referential null objects in Vedic Sanskrit and Ancient Greek. Acta Linguistica Hafniensia 44(2). 116-128.

Knjazev, Jurij P. 2007. Lexical reciprocals as a means of expressing reciprocal situations. In Vladimir P. Nedjalkov, Emma Š. Geniušene \& Zlatka Guentchéva (eds.), Reciprocal constructions, 115146. Amsterdam \& Philadelphia: John Benjamins. 
König, Ekkehard \& Peter Siemund. 2000. Intensifiers and reflexives: a typological perspective. In Zygmunt Frajzyngier \& Traci S. Curl (eds.), Reflexives: Forms and functions, 41-74. Amsterdam \& Philadelphia: John Benjamins.

König, Ekkehard \& Shigehiro Kokutani. 2006. Towards a typology of reciprocal constructions: focus on German and Japanese. Linguistics 44(2). 271-302.

König, Ekkehard \& Volker Gast. 2008. Reciprocity and reflexivity - description, typology and theory. In Ekkehard König and Volker Gast (eds.), Reciprocals and reflexives: Theoretical and cross-linguistic explorations, 1-32. Berlin \& New York: Mouton de Gruyter.

Krisch, Thomas. 1999. Zur Reziprozität in altindogermanischen Sprachen. In Heiner Eichner \& HansChristian Luschützky (eds.), Compositiones Indogermanicae in memoriam Jochem Schindler Gedenkschrift für Jochern Schindler, 275-297. Praha: Enigma corporation.

Kulikov, Leonid. 2007. Reciprocal constructions in Vedic. In Vladimir P. Nedjalkov, Emma Š. Geniušene \& Zlatka Guentchéva (eds.), Reciprocal constructions, 709-738. Amsterdam \& Philadelphia: John Benjamins.

Kulikov, Leonid. 2012. Vedic Preverbs as Markers of Valency-Changing Derivations. Studies in Language 34(4). 721-746.

Kulikov, Leonid. 2013. Middle and reflexive. In Silvia Luraghi \& Claudia Parodi (eds.), The Bloomsbury Companion to Syntax, 261-280. London, New Delhi, New York \& Sydney: Bloomsbury.

Kulikov, Leonid. 2014a. Grammaticalization of reciprocal pronouns in Indo-Arian: Evidence from Sanskrit and Indo-European for a diachronic typology of reciprocal constructions. Journal of South Asian Languages and Linguistics 1(2). 117-156.

Kulikov, Leonid. 2014b. The decline of labile syntax in Old Indo-Aryan: a diachronic typological perspective. Linguistics 52(4). 1139-1165.

LIPP = Dunkel, George E. 2014. Lexikon der indogermanischen Partikeln und Pronominalstämme. Band 2: Lexicon. Heidelberg: Winter. 
$\mathrm{LIV}^{2}=$ Rix, Helmut et al. 2001. Lexicon der Indogermanischen Verben. Die Wurzeln und ihre Primärstammbildungen. Wiesbaden: Reichert.

Logozzo, Felicia \& Paolo Poccetti. 2017. Ancient Greek Linguistics. New Approaches, Insights, Perspectives. Berlin \& New York: Mouton de Gruyter.

Lord, Albert B. 1960. The singer of tales. Cambridge, MA: Harvard University Press.

LSJ = The Online Liddell-Scott-Jones Greek-English Lexicon: http://stephanus.tlg.uci.edu/lsj/\#eid=1\&context=lsj.

Luraghi, Silvia. 2003a. Definite referential null objects in Ancient Greek. Indogermanische Forschungen 108. 169-196.

Luraghi, Silvia. 2003b. On the meaning of preposition and cases. The expression of semantic roles in Ancient Greek. Amsterdam \& Philadelphia: John Benjamins.

Luraghi, Silvia. 2010. The rise (and possible downfall) of configurationality. In Silvia Luraghi \& Vit Bubenik (eds.), Continuum Companion to Historical Linguistics, 212-229. London: Continuum.

Luraghi, Silvia. Forthcoming. Basic valency orientation, the anticausative alternation, and voice in PIE. To appear in the Proceedings of the 15. Fachtagung der Indogermanischen Gesellschaft. Wien (Austria), 13-16 September 2016.

Luraghi, Silvia, Guglielmo Inglese, Leonid Kulikov \& Martin Macak. Forthcoming. The passive voice in ancient Indo-European languages: inflection, derivation, compound verb forms. To appear in Michela Cennamo \& Claudia Fabrizio (eds.), Voice systems in diachrony. Amsterdam \& Philadelphia: John Benjamins.

Mackridge, Peter. 1985. The Modern Greek Language. Oxford: OUP.

Magni, Elisabetta. 2010. L'evoluzione semantico-funzionale dell'elelemto -th- nella morfologia verbale del greco. In Ignazio Putzu, Giulio Paulis, Gianfranco Nieddu \& Pierluigi Cuzzolin (eds.), La morfologia del greco tra tipologia e diacronia, 266-285. Milano: FrancoAngeli. 
Maslova, Elena. 2008. Reflexive encoding of reciprocity: Cross-linguistic and language-internal variation. In Ekkehard König \& Volker Gast (eds.), Reciprocals and reflexives: Theoretical and cross-linguistic explorations, 225-258. Berlin \& New York: Mouton de Gruyter.

Maslova, Elena \& Vladimir P. Nedjalkov. 2005. Reciprocal constructions. In Mattew S. Dryer \& Martin Haspelmath (eds.), The World Atlas of Language Structures Online. http://wals.info/chapter/106 (accessed 25 January 2019).

Nedjalkov, Vladimir P. 2007a. Overview of the research. Definitions of terms, framework, and related issues. In Vladimir P. Nedjalkov, Emma Š. Geniušene \& Zlatka Guentchéva (eds.), Reciprocal constructions, 3-114. Amsterdam \& Philadelphia: John Benjamins.

Nedjalkov, Vladimir P. 2007b. Encoding of the reciprocal meaning. In Vladimir P. Nedjalkov, Emma Š. Geniušene \& Zlatka Guentchéva (eds.), Reciprocal constructions, 147-208. Amsterdam \& Philadelphia: John Benjamins.

Nedjalkov, Vladimir P., Emma Š. Geniušene \& Zlatka Guentchéva (eds.). 2007. Reciprocal constructions. Amsterdam \& Philadelphia: John Benjamins.

Neri, Sergio. 2013. Zum urindogermanischen Wort für 'Hand'. In Adam I. Cooper, Jeremy Rau \& Michael Weiss (eds.), Multi Nominis Grammaticus. Studies in Classical and Indo-European Linguistics in Honor of Alan J. Nussbaum on the Occasion of his Sixty-Fifth Birthday, 185205. Ann Arbor: Beech Stave Press.

Parry, Adam (ed). 1971. The making of Homeric verse: the collected papers of Milman Parry. Oxford: OUP.

Puddu, Nicoletta. 2005. Riflessivi e intensificatori: greco, latino e le altre lingue indoeuropee. Pisa: ETS Edizioni.

Revuelta Puigdollers, Antonio R. 2007. Morfolgía y sintaxis: los compuestos verbales de ovv- en griego antiguo. In M. Esperanza Torrego, José M. Baños, Concepción Cabrillana, and Julian Méndez Dosuna (eds.), Praedicativa II: Esquemas de complementación verbal en griego antiguo y latín, 180-209. Zaragoza: Prensas de la Universidad de Zaragoza. 
Revuelta Puigdollers, Antonio. 2010. El pronombre $\dot{\alpha} \lambda \lambda \eta \dot{\eta} \lambda \lambda \omega v$ : entre la reciprocidad y la simetría. In José F. Gonzales Castro \& Jesús de la Villa (eds.), Perfiles de Grecia y Roma. Actas del XII Congreso Español de Estudios Clásicos, 133-142. Madrid: SEEC.

Revuelta Puigdollers, Antonio R. 2015. The verbal compounds of com- in Latin and the morphologysyntax interface. In Gerd V. M. Haverling (ed.), Latin Linguistics in the Early $21^{\text {st }}$ Century: Acts of the 16th International Colloquium on Latin Linguistics (Uppsala, June 6th-11th, 2011), 158-169. Uppsala: Acta Universitatis Upsaliensis.

Revuelta Puigdollers, Antonio R. 2017. Dis-compoound and recirpocal inter se in Latin. Pallas 103. $115-127$.

Romagno, Domenica. 2004. Ancora su preverbazione e sistemi verbali. Il caso dei preverbi greci. Archivio Glottologico Italiano 89(2). 165-180.

Romagno, Domenica. 2010. Anticausativi, passivi, riflessivi: considerazioni sul medio oppositivo. In Ignazio Putzu, Giulio Paulis, Gianfranco Nieddu \& Pierluigi Cuzzolin (eds.), La morfologia del greco tra tipologia e diacronia, 430-441. Milano: Franco Angeli.

Sausa, Eleonora. 2015. Argument structure constructions in Homeric Greek. A study on bivalent verbs. Pavia: Università degli Studi di Pavia dissertation.

Sausa, Eleonora. 2016. Basic valency orientation in Homeric Greek. Folia Linguistica Historica 37. $205-238$.

Sausa, Eleonora \& Chiara Zanchi. 2015. Non-accusative null objects in the Homeric Dependency Treebank. In Fancesco Mambrini, Marco Passarotti \& Caroline Sporleder (eds.), Proceedings of the Workshop on Corpus-Based Research in the Humanities (CRH). Warsaw: Institute of Computer Science.

Schwyzer, Eduard \& Albert Debrunner. 1950. Griechische Grammatik. Band 2: Syntax. München: Beck.

The Chicago Homer: http://homer.library.northwestern.edu/. 
Tummers, Jose, Kris Heylen \& Dirk Geeraerts. 2005. Usage-based approaches in Cognitive Linguistics: A technical state of the art. Corpus Linguistics and Linguistic Theory 1(2): 225261.

Vezzosi, Letizia. 2010. Micro-processes of grammaticalization. The case of Italian l'un l'altro. In Katerina Stathi, Elke Gehweiler \& Ekkehard König (eds.), Grammaticalization. Current views and issues, 343-372. Amsterdam \& Philadelphia: John Benjamins.

Viti, Carlotta. 2008. From space words to transitive markers: the case of Ancient Greek en 'in'. Transactions of the Philological Society 106. 375-413.

Viti, Carlotta. 2011. The use of the dual number in Homeric Greek. In Thomas Krisch \& Thomas Lindner (eds.), Indogermanistik und Linguistik im Dialog, 595-604. Wiesbaden: Reichert.

Watkins, Calvert. 1963. Preliminaries to a historical and comparative analysis of the syntax of the Old Irish verb. Celtica 6. 1-49.

Watkins, Calvert. 1964. Preliminaries to the Reconstruction of Indo-European Sentence Structure. Proceedings of the Ninth International Congress of Linguists. 1035-1045.

Watkins, Calvert. 1976. Toward Proto-Indo-European syntax: Problems and pseudo-problems. In Sanford B. Steever, Carol A. Walker \& Salikoko S. Mufwene (eds.), Proceedings of the Chicago Linguistics Society: Papers from the parasession on diachronic syntax, 305-326. Chicago: Chicago Linguistics Society.

Zaliznjak, Anna A. \& Aleksej D. Shmelev. 2007. Sociativity, conjoining, reciprocity, and the Latin prefix com-. In Vladimir P. Nedjalkov, Emma Š. Geniušene \& Zlatka Guentchéva (eds.), Reciprocal constructions, 209-230. Amsterdam \& Philadelphia: John Benjamins.

Zanchi, Chiara, Eleonora Sausa \& Silvia Luraghi. 2018. Hodel, a dependency lexicon for Homeric Greek: Issues and Perspectives. In Federico Giusfredi \& Paola Cotticelli-Kurras (eds.), Formal Representation and Digital Humanities, 230-256. Cambridge: Cambridge Scholars Publishing. 
Zanchi, Chiara. Forthcoming, 2019. Multiple preverbs in ancient Indo-European language. A comparative study on Vedic, Homeric Greek, Old Church Slavic, and Old Irish. Tübingen: Narr.

\section{Acknowledgements}

An earlier version of this paper was presented at the conference Corpus and Usage Based approach in Ancient Greek (University of Latvia, April 12-14 2018). We wish to express our gratitude to the conference participants and especially to Prof. Pierluigi Cuzzolin and Prof. José Luis García Ramón for their insightful comments. We also would like to thank the two anonymous reviewers as well as the journal's editors, whose critical remarks and observations have helped us greatly improve our paper. This paper results from joint work of the two authors. For academic purposes, Guglielmo Inglese is responsible of Sections 1, 2, 3.2,3.3 and 4 whereas Chiara Zanchi is responsible of Section $3.1,3.4,5,6$.

\section{Authors' information}

Guglielmo Inglese

email: guglielmo.inglese@kuleuven.be

KU Leuven, Department of Linguistics, Leuven, Belgium

\section{Chiara Zanchi}

email: chiara.zanchi01@unipv.it

Università degli Studi di Pavia, Dipartimento di Studi Umanistici - Sezione di Linguistica, Pavia, Italy 